\title{
The role of integration and clonal (1.) CrossMark expansion in HIV infection: live long and prosper
}

\author{
Elizabeth M. Anderson 10 and Frank Maldarelli*
}

\begin{abstract}
Integration of viral DNA into the host genome is a central event in the replication cycle and the pathogenesis of retroviruses, including HIV. Although most cells infected with HIV are rapidly eliminated in vivo, HIV also infects long-lived cells that persist during combination antiretroviral therapy (CART). Cells with replication competent HIV proviruses form a reservoir that persists despite CART and such reservoirs are at the center of efforts to eradicate or control infection without CART. The mechanisms of persistence of these chronically infected long-lived cells is uncertain, but recent research has demonstrated that the presence of the HIV provirus has enduring effects on infected cells. Cells with integrated proviruses may persist for many years, undergo clonal expansion, and produce replication competent HIV. Even proviruses with defective genomes can produce HIV RNA and may contribute to ongoing HIV pathogenesis. New analyses of HIV infected cells suggest that over time on CART, there is a shift in the composition of the population of HIV infected cells, with the infected cells that persist over prolonged periods having proviruses integrated in genes associated with regulation of cell growth. In several cases, strong evidence indicates the presence of the provirus in specific genes may determine persistence, proliferation, or both. These data have raised the intriguing possibility that after CART is introduced, a selection process enriches for cells with proviruses integrated in genes associated with cell growth regulation. The dynamic nature of populations of cells infected with HIV during cART is not well understood, but is likely to have a profound influence on the composition of the HIV reservoir with critical consequences for HIV eradication and control strategies. As such, integration studies will shed light on understanding viral persistence and inform eradication and control strategies. Here we review the process of HIV integration, the role that integration plays in persistence, clonal expansion of the HIV reservoir, and highlight current challenges and outstanding questions for future research.
\end{abstract}

Keywords: HIV persistence, HIV reservoirs, Proviral integration, Clonal expansion

\section{Background}

Despite the success of combination antiretroviral therapy (cART) to block viral replication and halt disease progression, HIV viremia persists in the blood and anatomic compartments for years after therapy is initiated [1]. Although current therapies improve morbidity, mortality, and quality of life [2-5], long-term cART is associated with drug toxicities and persistent immune activation that contributes to morbidity and mortality, including a higher risk for non-AIDS related diseases including cardiovascular disease, cancer, kidney disease, liver disease,

*Correspondence: fmalli@mail.nih.gov

HIV Dynamics and Replication Program, NCI, NIH, Frederick, MD 21702, USA neurologic disease, and bone diseases $[3,6,7]$. Furthermore, if antiretroviral treatment is interrupted, viremia rebounds to near pre-therapy levels within weeks in most patients [8-10]. As a consequence, developing strategies to eradicate or control HIV without antiretroviral therapy are a high priority [11]. HIV rebounds from a reservoir of latently infected cells and consistent with this, the rebounding virus is archival in nature [12]. The source of persistent residual viremia that gives rise to rebounding virus upon treatment interruption remains largely unknown and is paramount for HIV cure initiatives.

A hallmark of retroviruses, and a key step in the HIV replication cycle that enables viral persistence, is the integration of the HIV DNA into the host genome. Integration is a multistep process that involves both viral and 
host factors resulting in a stable and irreversible positioning of the double stranded reverse transcription product, the provirus, within the host cell. Integration does not require that the viral DNA be replication competent or even full length, and integration may proceed with highly deleted genomes. The choice of location of the retrovirus integration site within the host genome is neither entirely random nor specifically targeted. Integration preferences for various retroviruses have been identified and influence locations within the host genome where proviral integration takes place [13, 14]. Upon integration, the HIV provirus persists for the life of the cell and transcription of viral mRNA is coordinated by host cellular mechanisms. HIV primarily infects activated CD4+ T cells, a small subset of which may transition back to a resting memory state that is non-permissive for viral gene expression [15]. Although resting cells largely restrict productive HIV infection (reviewed by Zack et al. [16]), HIV can directly infect resting cells in vitro $[17,18]$ providing an alternative mechanism for establishing latency. In either case, a reservoir of latently infected cells may be unaffected by host immune responses and have a very long half-life [19-22].

HIV integration into long-lived cells represents an intrinsic characteristic that is central to HIV persistence and therefore a major barrier to an HIV cure or control strategy. During cART, lymphocyte populations undergo substantial change as ongoing HIV transmission is blocked, and a degree of immune restoration occurs. The population of HIV infected cells is molded over time since these cells may persist, be lost, or undergo clonal expansion. Understanding immune and viral mechanisms responsible for persistence is essential to characterizing the population of infected cells harboring replication-competent HIV that remain on therapy for prolonged periods and are a primary objective of control and eradication.

The only HIV reservoir that gives rise to rebounding virus, making a cure unachievable as of yet, is the reservoir of replication competent proviruses. Although over 95\% of all integrated proviruses are defective or deleted, a small fraction of inducible replication competent proviruses persist for years on cART [23]. Still, defective and deleted proviruses are capable of producing viral proteins which can be targeted by the immune system and may contribute to persistent immune activation and longterm HIV pathogenesis [24, 25]. The majority of replication competent HIV proviruses persist in resting CD4+ $\mathrm{T}$ cells of a memory phenotype [21]. Since HIV gene expression is dependent on host transcription factors that are present only during cellular activation, HIV transcription is nearly silenced in resting CD4+ T cells. This results in a stably integrated yet transcriptionally silent provirus that will persist for the life of the cell, and can be reactivated to produce infectious virus. Resting CD4+ memory $\mathrm{T}$ cells have a very long half-life [19] and even after years on cART, resting CD4+ memory $\mathrm{T}$ cells can maintain themselves in a quiescent state or through periodic cell division without reactivation of the latent virus.

The HIV reservoir is established early during primary infection and is remarkably stable with a half-life of 43-44 months [26, 27]. As a consequence, current suppressive therapies must be maintained in an individual for over 70 years to achieve complete elimination of the reservoir. Similarly, HIV DNA levels remain detectable and are stable in most patients after years on suppressive therapy [28]. HIV reservoir half-life determinations vary substantially, in part due to technical approaches. Measurements of HIV DNA vary according to the HIV proviral target measured, for example LTR compared to gag. Determining the number of cells with infectious HIV proviruses may vary depending on the distinct quantitative viral outgrowth assay in use [29]. Understanding the underlying mechanisms that determine the variability in reservoir half-life will shed light on how the reservoir decays and whether immune selection pressure influences the rate of decay. The intrinsic stability of the reservoir indicates that its long term maintenance is a major mechanism that supports HIV persistence. The latent reservoir can be maintained over the course of cART through periodic homeostatic proliferation and through clonal expansion of HIV infected cells, both antigen mediated and integration site driven (reviewed by Murray et al. [30]). Additionally, promotion of cell survival through antiapoptotic regulation (reviewed by Badley et al. [31]) or the integration of proviruses into certain genes may also enable cells harboring integrated proviruses to persist for prolonged periods. Targeting the mechanisms for reservoir maintenance may provide novel curative strategies to deplete the latent reservoir.

Fundamental to bridging knowledge gaps towards HIV eradication is an understanding of the establishment and maintenance of cellular reservoirs and their persistence. The dramatic example of HIV cure [32, 33], as well as accumulating reports of post treatment control without cART [34-38] suggests that viral eradication or longterm viral remission may be achievable. Further study of proviral integration and persistence will aid in the development of novel strategies towards an HIV cure. A number of reviews on integration details have been published in the last several years that summarize aspects of integration and persistence including integrase structure and enzymology [39, 40], recent methods of detecting and quantitating integration sites [41, 42], as well as studies on other retroviruses integration that have useful insights for understanding persistence of HIV infected cells [43]. 
Here, we review concepts and controversies regarding HIV integration and clonal expansion of infected cells in the setting of current understanding of host cell populations, and highlight unanswered questions for future research.

\section{Dynamics of HIV infected populations \\ Establishing a reservoir for HIV}

Characterizing HIV persistence during prolonged cART requires a fundamental understanding of infected cell populations and their dynamics in infected individuals during cART. HIV infects numerous host cell types in diverse anatomic compartments typical of cells of lymphocyte [44] and myeloid lineage [45]. Various CD4+ T cell subsets are infected, but only some are likely sources of long-term persistence. Activated cells are typically infected by HIV and frequently undergo cell death from viral induced or immune elimination. Infrequently, activated $\mathrm{CD} 4+\mathrm{T}$ cells infected with HIV transition to a resting memory state that is only poorly permissive for viral gene expression if at all $[20,21,46]$. These latently infected cells have a very long half-life [19] and in the absence of any viral gene expression may evade host immune responses. New studies to address whether cells remain latent permanently and whether they may evade immune surveillance are necessary. The memory $\mathrm{T}$ cell pool is composed of two main compartments, central memory $\left(\mathrm{T}_{\mathrm{CM}}\right)$ and effector memory $\left(\mathrm{T}_{\mathrm{EM}}\right) \mathrm{T}$ cells, which are characterized by their homing abilities and effector functions [47, 48]. An intermediate compartment has also been described and is designated as the transitional memory compartment $\left(\mathrm{T}_{\mathrm{TM}}\right)$. Both $\mathrm{T}_{\mathrm{CM}}$ and $\mathrm{T}_{\mathrm{EM}}$ compartments persists for decades [49] however the kinetic behaviors of these populations differ [50]. $\mathrm{T}_{\mathrm{CM}}$ have a high proliferative capacity and are long-lived [51]. On the other hand, $\mathrm{T}_{\mathrm{EM}}$ are rapidly turned over constituting a short-lived population with an extremely low proliferative capacity [50].

Another potential contributor to the HIV reservoir is a less differentiated subset of long-lived memory $\mathrm{T}$ cells with a high self-renewal capacity known as stem-cell memory $\mathrm{CD} 4+\mathrm{T}$ cells $\left(\mathrm{T}_{\mathrm{SCM}}\right)$ [52]. $\mathrm{T}_{\mathrm{SCM}}$ can be differentiated from naïve $\mathrm{T}$ cells via TCR stimulation in vitro supporting the idea that naïve $\mathrm{T}$ cells represent the precursor to $\mathrm{T}_{\mathrm{SCM}} \cdot \mathrm{T}_{\mathrm{SCM}}$ retain many phenotypic characteristics of naïve $\mathrm{T}$ cells (CD45RA+ and CCR7+) but additionally express memory $\mathrm{T}$ cell markers including CD95 and CD62L [52]. $\mathrm{T}_{\mathrm{SCM}}$ are infected by HIV in vitro, however, only a small fraction of cells are able to support productive infection [53]. Still, prolonged survival of $\mathrm{T}_{\mathrm{SCM}}$ indicate that they may become the dominating population in the reservoir after long term suppression when ongoing rounds of virus replication are halted and other memory
$\mathrm{T}$ cell compartments decay. Indeed, Buzon et al. found $\mathrm{T}_{\mathrm{SCM}}$ infected cells contribute minimally after 1 year on suppressive therapy but their contribution increased after long term therapy [54]. These findings suggest that HIV infected $\mathrm{T}_{\mathrm{SCM}}$ cells could comprise a viral niche that promotes long-term viral persistence. Furthermore, replication competent virus has been recovered from CD45+/CD62L + memory T cells ex vivo [55]. Given the potential for $\mathrm{T}_{\mathrm{SCM}}$ to survive for prolonged periods and maintain a high proliferative capacity, it is critical to determine the contribution of the $\mathrm{T}_{\mathrm{SCM}}$ compartment to the HIV reservoir.

Recent reports suggest additional helper $\mathrm{T}$ cell populations are infectable by HIV. As described by Lichterfeld and coworkers, these additional $\mathrm{T}$ cell populations express sufficient CXCR4 (Th1, Th17), or CCR5 (Th2 and Th9) to be infected in vitro by X4 and R5 tropic HIV respectively [56]. Extensive cell sorting studies recovered HIV DNA from these subsets in HIV infected individuals, indicating they are infected in vivo. The longevity of these subsets remains uncertain, but they are reported to have long half-lives, and thus may represent relevant reservoirs for HIV infection.

Other cell lineages, including tissue resident cells may be infected with HIV and may represent important sources of persistence of HIV infected cells during cART [57]. Intriguingly, HIV infection occurring at the stem cell level [58-60] raises the possibility that other downstream lymphocyte lineages, including B cells, may contain HIV proviruses. Although routine analyses of B cells does not typically detect HIV proviruses, infection may be present at levels below assay limits. Collins et al. have reported the presence of such cells as well as hematopoietic stem cells (HPC) infected with HIV at low frequency [61] and have suggested HPC infection may occur in only a subset of patients [60]. Others have published conflicting reports on the presence of HIV infected HPC in vivo $[62,63]$. It is essential to determine if long-lived hematopoietic stem cells also contribute to the HIV reservoir. Additional potential reservoirs for HIV infection have been reported in myeloid lineages, including brain macrophages [64-66] and astrocytes [67, 68] in the central nervous system, and podocytes in the kidney [69]. The relevance of HIV infection of these long-lived cells as reservoirs for HIV infection during long-term cART is actively under investigation.

\section{Maintaining a reservoir of HIV infected cells during cART} Longstanding untreated infection is characterized by progressive loss of lymphocytes with a preferential decline in CD4+ cells, and consequently a decrease of CD4/CD8 ratios. As described above, not all HIV infected cells are rapidly eliminated. The proportion of all lymphocytes 
that are infected is relatively low (1:100-1:1000). As such, the progressive loss of $\mathrm{CD} 4$ cells that is characteristic of untreated HIV infection is not due to direct viral killing per se, but to associated mechanisms, such as bystander effects and activation-induced cell elimination. Longlived infected cells are less frequent, and are revealed upon initiating cART. The frequency of HIV DNA+ cells declines within the 1-4 years on cART, but remains relatively stable thereafter within the range of 1-3 per 10,000 CD4 cells during therapy [28]. As reviewed in this Special Issue by Pinzone and O'Doherty [70], determining levels of integrated HIV DNA can shed light on how reservoirs are maintained during cART. Prior to treatment initiation, total and integrated HIV DNA levels are higher in individuals treated during chronic HIV infection and decrease to a lower extent than those treated in primary HIV infection [71-73]. Furthermore, integrated HIV DNA continues to decay after prolonged therapy in individuals treated during primary infection suggesting that enhanced immune responses in these individuals are able to clear HIV infected cells more effectively [72, 74, 75]. During this same period, CD4 cell numbers typically increase with a measure of immune restoration. Thus, the number of infected cells keep pace with the overall recovery of CD4 cells. During prolonged cART, infected cells persist, are lost, or undergo clonal expansion in the context of a dynamic (and aging) immune cell population. It is not known how the proportion of infected cells remains stable as CD4 numbers rise, but it is likely that infected cells respond to immune signals to persist and proliferate. As such, the abundance of HIV infected cells in $\mathrm{T}$ cell subsets during cART may be continually molded by immune forces. The factors driving the maintenance of infected cells is of critical interest in understanding persistence and have been broadly divided into homeostatic and direct immune stimulatory factors [76].

Latently HIV infected resting memory CD4+ T cells can undergo homeostatic proliferation and antigen mediated or integration site driven clonal expansion [77-80] which may maintain the reservoir during cART. T cell homeostasis is a state of equilibrium maintained through self-regulation of $\mathrm{T}$ cell pools. $\mathrm{T}$ cells present in circulation and residing in tissues provide afferent and efferent immune arms that are central to both adaptive and innate immune responses. T cell homeostasis is mediated by homeostatic cytokines that belong to the common $\gamma$ chain cytokine family including IL-2, IL-4, IL-7, IL-9, IL-15, and IL-21. A strong inverse correlation between baseline CD4 count and IL-7 plasma levels has been described, but the factors associated with this correlation have not been identified [81-83]. Lymphocyte population dynamics has been directly investigated using in vivo bromodeoxyuridine (BrdU) labeling. These studies found that the increase in IL-7 is the result of CD4 depletion, but is not the primary driver of CD4 proliferation in the context of HIV infection [84]. Conversely, IL-15 controls survival and turnover of memory CD4+ T cells. Patients with advanced HIV infection have increased type I IFN plasma levels. Ongoing exposure to homeostatic forces and type I IFN activation may be responsible for selective depletion of CD4+ T cells [85]. IL-7 increases the number of $\mathrm{CD} 4+\mathrm{T}$ cells by promoting their survival and proliferation, providing a rationale for IL-7 treatment to assist immune reconstitution in the setting of HIV infection $[86,87]$. However, IL-7 induces proliferation without virus reactivation indicating that homeostatic proliferation can maintain the reservoir over time $[88,89]$.

Antigenic stimulation driven either by specific common antigens (CMV, EBV, HPV) or nonspecific immune activators, such as bacterial cell products translocated across the leaky gut wall that is present in HIV infection, may induce generalized immune activation and could ultimately contribute to the clonal expansion of HIV infected cells. IL-2 is produced by CD4+ T cells following activation by an antigen and drives $\mathrm{T}$ cell proliferation [90]. It is possible that HIV infected cells can undergo clonal expansion in response to cognate or cross reacting antigens. HIV-specific CD4+ T cells are a favored target for HIV infection [91]; it is likely these HIV specific cells persist during therapy, and that low level HIV production during cART may continue to drive persistence and expansion of these specific subsets. Other antigens commonly encountered (e.g., CMV, EBV) may also represent potential sources of clonal expansion. We previously reported a cell clone that was widely anatomically distributed, but significantly enriched in cancer metastases, suggesting that these cells proliferated in response to the cancer antigen [79]. Specific T cell receptor analyses were not possible in this single example. Advances in $\mathrm{T}$ cell receptor characterization of individual HIV infected cell clones will be critical for understanding the role of antigen driven clonal expansion on shaping the proviral landscape. These different mechanisms can promote cellular clonal expansion to maintain or potentially increase the size of the latent reservoir of intact replication competent proviruses.

HIV infection is characterized by a state of chronic immune activation which may play a strong role in maintaining persistence and clonal expansion of HIV infected cells. Prior to cART, viremia is substantial and activated CD4+ T cells infected with HIV die rapidly with a halflife of approximately 1.5 days which can be attributed to a variety of cytopathic effects. During chronic HIV infection and in the absence of treatment, abortive infection leads to the release of inflammatory cytokines that contribute to chronic inflammation, CD4+ T cell depletion, 
dysregulation of $\mathrm{T}$ cell homeostasis and ultimately AIDS [92, 93]. Even after the introduction of cART, low level viremia persists likely as the result of the stochastic reactivation of latently infected cells [94], infected cells are slowly eliminated [26, 27], but HIV antigens continue to persist thereby potentially contributing to chronic immune activation and dysregulation [95, 96]. Previous work measuring the decay kinetics of integrated HIV DNA from individuals treated during chronic HIV infection suggest diminished immune responses could promote persistence with the inability to effectively eliminate HIV infected cells during therapy. We recently found HIV infected cells harboring proviruses that contain internal HIV genes (such as gag) decline at a faster rate than $g a g$ lacking proviruses upon cART initiation [76]. These findings further suggest a potential role for immune pressure to shape the proviral landscape during cART. Finally, in addition to generalized systemic immune activation, HIV mediated inflammation may be anatomically restricted [97]. Understanding the forces driving persistence and clonal expansion of resident $T$ cells in tissues will shed important light on the mechanisms of HIV persistence and pathogenesis in vivo.

\section{Detecting reservoirs of HIV infected cells and their turnover}

Recent lines of research may improve our understanding of lymphocyte kinetics, and critical advances for quantifying HIV reservoirs are essential (Reviewed in this Special Issue by Wang et al. [98]). The simplest way to determine the viral burden in various cell subsets uses standard PCR-based techniques that measure total HIV DNA but is unable to distinguish integrated from unintegrated forms of HIV DNA. The utility of measuring integrated HIV DNA to understand how reservoirs are formed and persist is reviewed in this Special Issue by Pinzone and O'Doherty [70]. To date, HIV DNA has been measured in total peripheral blood mononuclear cells (PBMCs) [99], CD4+ T cells [100], resting CD4+ $\mathrm{T}$ cells [101], as well as in the gut-associated lymphoid tissue (GALT) [102, 103]. Recent approaches have used a next generation platform of PCR called droplet digital PCR (ddPCR) (Reviewed in this Special Issue by Rutsaert et al. [104]). ddPCR utilizes absolute quantification rather than relative quantification based off extrapolating from a standard curve in traditional qPCR. Eliminating the error from user generated or instable standard curves enables ddPCR to be more accurate than qPCR [105]. Furthermore, PCR inhibition is limited since the bulk PCR reaction is partitioned into circa 20,000 individual reactions. ddPCR has been used to quantify total HIV DNA in vivo from PBMCs, CD4+ T cells, $\mathrm{T}$ regulatory (Treg) cells, and in cells from cerebrospinal fluid [29, 106-110].

Despite these advances, total HIV DNA quantification using standard PCR-based techniques has been shown to be at least two orders of magnitude higher than latent reservoir size measurements using the quantitative viral outgrowth assay (qVOA), the gold standard technique to measure the replication competent reservoir [29]. This large discrepancy is likely due to the fact that the majority of integrated proviruses are deleted [111], therefore total HIV DNA alone cannot provide an accurate estimate of latent reservoir size. Still, HIV DNA levels remain an important biomarker for viral persistence [112] and can predict viral rebound upon treatment interruption $[9$, 113]. Moreover, HIV DNA levels strongly correlate with qVOA thereby providing a surrogate marker for the size of the latent reservoir using an inexpensive and less time consuming approach $[29,114]$. New duplexed ddPCR strategies that quantify internal targets may improve the accuracy of amplification methods to quantify replication competent reservoirs [115].

Understanding lymphocyte dynamics and turnover is a second critical area requiring advancement. In the context of HIV infection, persistent immune activation is associated with an increase in cell proliferation and cell death. In vivo labeling can provide reliable measurements of cell turnover and proliferation. Labeling newly synthesized DNA with deuterium provides a method for directly measuring turnover in a population of cells, with the caveat that minority populations cannot be studied easily. BrdU is a thymidine analogue that is incorporated into the DNA of replicating cells and can subsequently be detected by flow cytometry with a monoclonal antibody [116]. In vivo BrdU labeling identified two populations of CD4 and CD8 T lymphocytes which can be characterized as either rapidly proliferating or slowly proliferating [117]. Activated cells have the highest proliferative rates, followed by effector and central memory, and naïve cells have the lowest proliferative rates [84]. Increased CD4+ T cell turnover is associated with higher HIV plasma RNA levels and increased CD4 depletion, suggesting that lymphocyte turnover is a direct consequence of HIV infection [117]. Additionally, immune responses also play a role in the turnover of most CD4 and CD8 memory cell subsets [84]. On the other hand, turnover of the naïve compartment can be attributed to homeostatic mechanisms rather than immune mediated activation [84]. Long term labeling with deuterated water found $\mathrm{T}$ cell subpopulations possess distinct half-life characteristics and that $\mathrm{T}$ cells died more rapidly in individuals with advanced HIV infection [118]. Continuing research to measure the turnover of cells, including HIV infected cells, in these subsets is crucial to determine the 
longevity of these compartments and their role in promoting long-term persistence of HIV infected cells.

Further definition of the spectrum of cell subsets infected by HIV is also essential. Novel single cell and transcriptomic studies [119-122], as well as quantitative studies of populations of CD4 and CD8 cell subsets are advancing our understanding of human immune response to pathogens, including chronic infections, and may potentially inform the status of HIV infected cells with integrated proviruses. To date, single cell methods have been useful in characterizing the fate of $\mathrm{T}$ cells [122]. Understanding the functionality and dynamics of $\mathrm{T}$ cell populations over prolonged periods as individuals age is especially germane [123-125]. Since the frequency of HIV infected cells during cART is low, functional studies of $\mathrm{T}$ cells infected with HIV necessitates innovative approaches that overcome technical challenges to characterizing individual infected cells.

\section{Integration: the central event in HIV replication}

The integration of the HIV provirus into the host genome is a key characteristic of retroviruses and an essential step in the HIV life cycle that enables viral persistence. Prior to integration, the virally encoded enzyme reverse transcriptase (RT) synthesizes a linear double-stranded cDNA intermediate from the viral RNA genome. This reverse transcription product is the substrate for integration and contains homologous long terminal repeat (LTR) sequences at both the $5^{\prime}$ and $3^{\prime}$ ends [126]. The process of integration is the product of a viral enzyme, integrase, but interactions with other viral and cellular factors are required for successful integration to take place in an in vivo setting.
Integrase structural and enzymatic studies

Integrase (IN) is a member of the transposase family of nucleotidyl transferases (E.C. 2.7.7) that catalyze the transfer of $3^{\prime} \mathrm{OH}$ ends of HIV DNA to a host DNA acceptor. IN has a tripartite structure consisting of an $\mathrm{N}$ terminal Domain (NTD), a catalytic core domain (CCD) and a C-terminal domain (CTD). NTD and CTD have important functions coordinating interactions with DNA and chromatin binding. CCD contains enzymatic activity, including a D, D, E active site motif that is found in a number of nucleotidyl transferases, which coordinates essential divalent metal cations necessary for catalysis (Fig. 1).

Understanding the structure and function of integrase has been critical to explain the establishment of the provirus and for developing integrase inhibitors. The structure of HIV integrase has been the subject of intense investigation; crystals of the catalytic portion of HIV IN have been available for years [127], but the full length enzyme has had technical issues [128, 129]. Fortunately, pivotal studies of foamy virus and maedi-visna virus integrase have greatly advanced the field [130-132] and revealed critical structural characteristics of integration [133, 134]. These studies utilized crystallographic approaches of integrase and DNA substrate co-crystals and cryo-electron microscopy (cryo-EM) approaches of integrase multimers and DNA. Structural studies combined with biochemical studies using in vitro assays of purified HIV IN enzyme and host DNA have characterized the multistep process of HIV integration (Fig. 2). HIV IN multimers are positioned at the ends of DNA product. The initial structure, denoted the intasome or stable synaptic complex, is poised to initiate the multistep integration reaction, beginning with an IN-mediated 2 nucleotide deletion at the $3^{\prime}$ end of each viral DNA

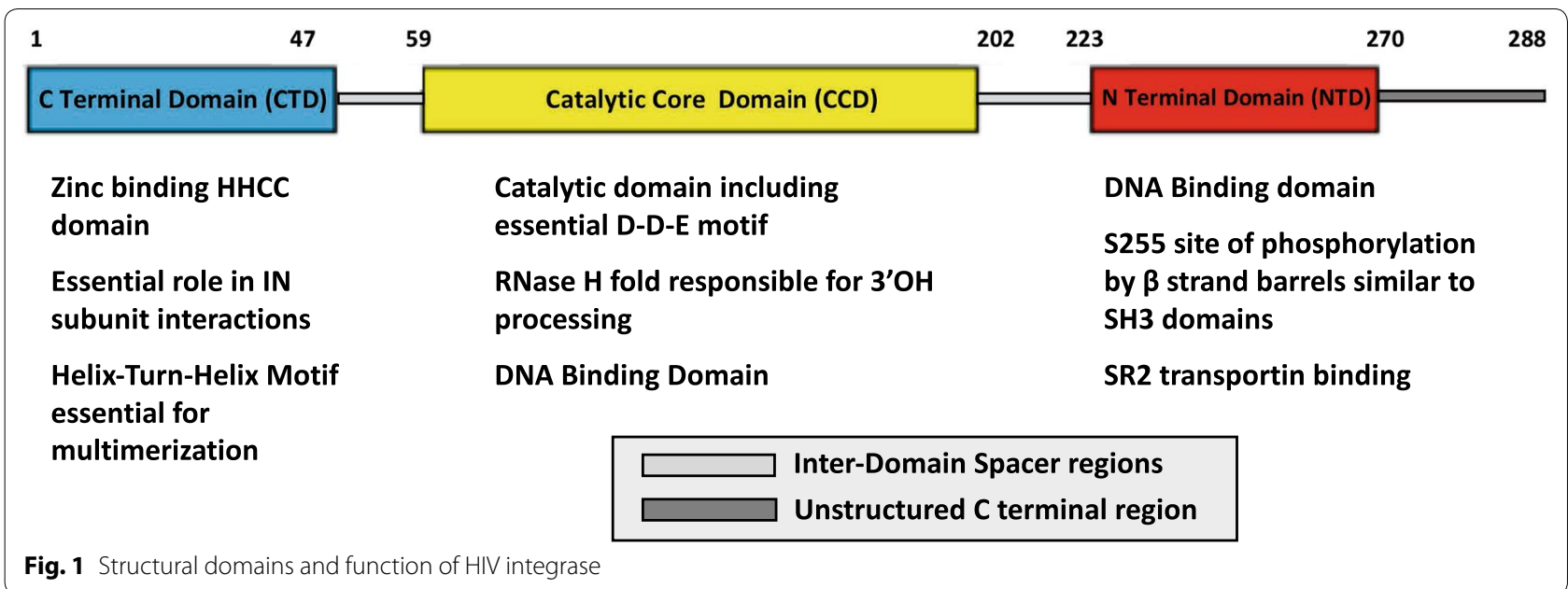




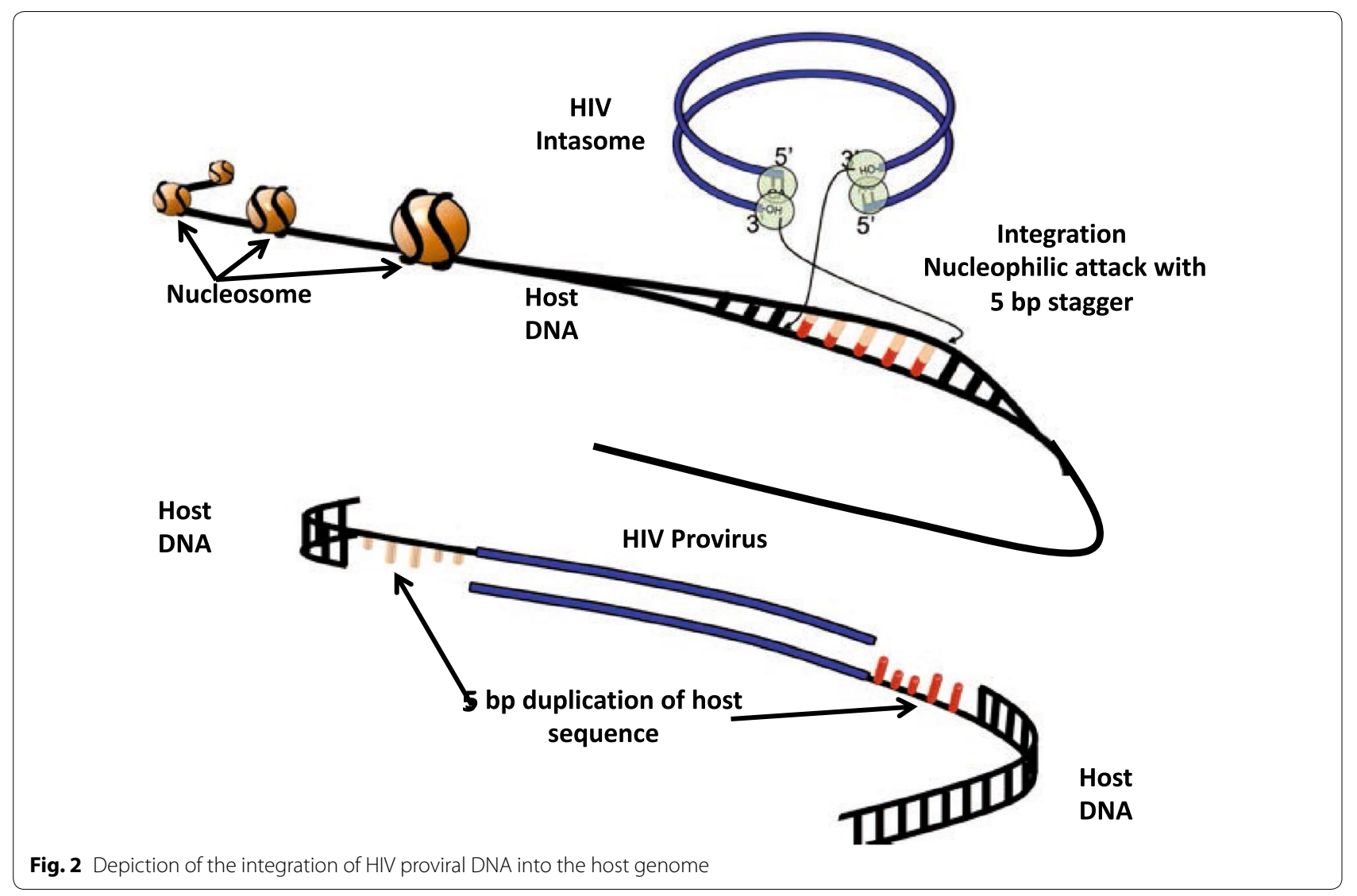

molecule, creating staggered ends on the viral substrate for subsequent integration into the host DNA.

The stoichiometry of Integrase:DNA has been a subject of intense interest to discern the processes that coordinate the integration reaction. Furthermore, specific inhibitors that disrupt multimerization are currently in therapeutic development. A number of studies have suggested that IN from HIV and other retroviruses assumes a quaternary structure at the ends of the proviral DNA molecules [133]. Over the last several years, the development of cryo-EM has revolutionized the visualization of large macromolecular assemblies. Cryo-EM has permitted the visualization of HIV IN structure that has not been previously possible through traditional crystallographic approaches. Intriguing new cryo-EM studies have identified structures for HIV IN containing more than four IN molecules. The relative contributions of these higher order structures to integration and interactions with elements of the PIC remain uncertain and are topics of active investigation [135]. The development of a new class of IN inhibitors, called allosteric integrase inhibitors (ALLINIs), will be particularly useful probes in understanding the role of higher order structures in HIV IN (reviewed by Feng et al. [136]). ALLINIs bind at the IN dimer interface resulting in aberrant IN multimerization, with a number of critical consequences for HIV replication, including the production of aberrant particles with viral ribonucleoprotein eccentrically localized in virions [136]. These defective virions have reduced reverse transcriptase activity and accelerated decay rates of viral RNA in subsequent rounds of replication [137-140]. Thus, disruption of proper IN multimerization has consequences for both early and late steps in HIV replication.

The details of binding and cutting host sequences has been extensively studied in model systems. In cryo-EM studies of maedi-visna integrase, tetramers assembled at each DNA end (with 2 nucleotides at the $3^{\prime}$ end of each viral DNA molecule already removed), then the CTDs bind in expanded major grooves of DNA targets effectively bending the target DNA [141]. Once bound, a target capture complex cuts the host DNA with a 5 nucleotide staggered cut yielding the strand transfer complex (Fig. 2) (for details see Lesbats et al. [142]), enabling transfer of the viral DNA to host cell DNA. The intervening 5 nucleotide gap is filled in by host DNA polymerase, and ligated by host ligase. One consequence of the 5 nucleotide staggered cutting mechanism of the host DNA by integrase is the duplication of these 5 nucleotides of host sequence 
directly flanking the $5^{\prime}$ and $3^{\prime}$ ends of the provirus, which provides a useful assay to confirm authentic integrations when both the $5^{\prime}$ and $3^{\prime}$ sites have been sequenced.

The extraordinary detail afforded by crystallographic and cryo-EM studies combined with an extensive understanding of IN enzymology, the role of specific domains involved in IN enzymatic activity (Fig. 1), and the effects of type I and II mutations provides a strong foundation for understanding the role of IN in HIV replication and identifying new avenues for HIV IN therapeutic development.

\section{Determinants of integration site selection}

In in vitro assays of purified integrase, integrases show little host site specificity, with the exception of weak palindromic sequences at target sites [14]. In contrast, analyses of integration site distribution in retroviral tissue culture infections and in samples from animal studies or patients reveal integration site preferences that highly influence the overall infection program. Preferences are exercised by the cellular partners that the intasome engages during the transport to the nucleus and integration. As described by Ciuffi [143], Craigie [144], and Debeyser $[145,146]$, these factors may be categorized as those with chaperone-like activity and those with chromatin-tethering activity. Understanding nuclear import and chromatin association is essential to understanding distribution of integration sites, as interactions with tethering and chaperone partners may have direct and indirect effects on distribution of integration sites. Cofactors for integration have been investigated for a number of retroviruses. As reviewed by Engleman [147], some retroviruses have distinct integration preferences, while others remain relatively random. Here we will review data for HIV.

Unlike many retroviruses, HIV infects non-dividing cells, requiring import of the reverse transcript into the nucleus which takes place in the context of a large multimeric pre-integration complex (PIC). PIC contents remain under study (reviewed in Suzuki \& Craigie [148] and Craigie \& Bushman [144]), as understanding the composition of the PIC will provide insights into requirements for initial steps in establishing the proviral state and potential targets for interruption in non-dividing cells. Viral components include HIV RT, IN, and an uncertain portion of the complement of HIV CA from the incoming core are associated with the PIC. Cellular proteins interacting with the PIC include the barrier to autointegration factor 1 (BAF1), high mobility group proteins (HMG), lamina-associated polypeptide $2 \alpha$ (LAP2 $\alpha$ ), lens-epithelium-derived growth factor (LEDGF/p75), and the karyopherin transportin SR2 (TRN-SR2, TNPO3). TNPO3 binds directly to the CCD and CTD of IN [149] and may participate in shuttling the PIC to the nucleus. The size of the PIC is uncertain, but it must fit through the nuclear pore, and the process of import is essential yet remains unclear. As IN associates with the ends of the HIV DNA, the internal HIV sequence need not be full length, and can be defective or deleted, making the HIV proviral makeup in an individual highly diverse. As reverse transcription may take place in the nucleus [150], $\mathrm{RT}$ and associated factors may clearly be imported into the nucleus.

A number of critical outstanding questions defining the early events of infection are currently under study. These include the requirements for uncoating and transport, the composition of PIC structures, the factors required for intracellular transport and nuclear import, the coordinated involvement of cellular and nuclear cytoskeletal structures, as well as the overall kinetics and rate limiting steps of the process. A number of factors have been reported to be involved in regulating import, including nuclear membrane proteins SUN1 and SUN2 [151]. The central role for integration in HIV replication makes it an attractive target for therapy. Enzymatic inhibitors have been highly successful, allosteric inhibitors or agents that interrupt other integrase functions such as multimerization or interactions with cellular proteins have already yielded interesting candidates for further study [136, 152-154]. Critical advances in tracking single particles with elegant microscopic approaches have begun to characterize the kinetics of nuclear import [150, 155].

Once nuclear import has been accomplished the provirus can integrate into the host genome. The site of proviral integration for retroviruses is relatively nonspecific, with general preferences among the orthoretrovirinae subfamily. For HIV, integration site preferences include actively transcribed genes, gene rich regions of chromosomes, introns over exons, and generally exclude promoter regions. As introns are typically much larger than exons, the excess integrations into introns is likely due to larger overall size of introns rather than a functional constraint or preference per se. Preferences for activated genes [156] are generally mediated by cellular cofactors that bind IN [157]. As described by Ciuffi [158] and Debeyser [145, 146], these factors may be categorized as those with chaperone-like activity that are primarily involved in nuclear import, and those with chromatintethering activity.

Chief among the factors coordinating binding to chromatin is the transcriptional activator LEDGF/p75 [159]. Co-crystal studies identified contacts between the integrase CCD and CTD of two IN molecules and the C-terminal integrase binding domain (IBD) in LEDGF/p75 [132]. These findings suggest that LEDGF/p75 forms a bridge between the NTD domain of one IN dimer and 
two CCD domains of a second dimer [132, 143, 160]. The LEDGF/p75 N-terminal domain contains an AThook motif which mediates DNA-binding at AT-rich regions [143], and a PWWP domain that mediates binding to chromatin [161]. LEDGF/p75 knock down experiments showed no decrease in the ability of HIV DNA to integrate into the host genome, but revealed shifts the integration site distribution away from transcriptionally active and AT-rich regions [159]. In a series of domain swapping experiments, Hughes and coworkers demonstrated that replacing the AT hook and PWWP domains of LEDGF/p75 with the chromatin binding domains of proteins having euchromatin or heterochromatin binding specificities redirects integration according to the specificity of the heterologous binding domain [162]. These studies highlight the critical role of LEDGF/p75 and demonstrate approaches to manipulate integration that may be useful in the design of safer retroviral vectors [162].

Recent reports have investigated the role of nuclear architecture in integration preferences. HIV enters via nuclear pore complexes (NPCs) into regions that are typically euchromatin rich as a result of $\mathrm{Tpr}$, a protein constituent of the NPC basket region that facilitates heterochromatin exclusion zones [163]. Tpr knock down results in chromatin reorganization and no exclusion of heterochromatin from NPC regions, but does not reduce HIV integration although HIV transcription is significantly impaired $[159,164]$. These findings indicate that in the absence of Tpr, HIV integration continues directly after or in concert with nuclear import but into regions that are unfavorable for HIV transcription [164]. Marini et al. analyzed the topologic distribution of HIV integration sites and reported highest levels of integration in genes located near NPCs with a decreasing gradient of integration in genes at greater distance from the nuclear envelope [165]. There are a number of techniques to localize HIV proviruses within nuclei: labeling of nascent HIV DNA with 5-ethynyl-2'-deoxyuridine (EdU) and immunofluorescent detection [166], identifying integrated proviruses by immunolocalization of endonucleases that introduce specific double strand breaks in HIV [167], detecting HIV proviruses in live cells using quantum dot labeled Transcription Activator-Like Effectors (TALEs) [168], colocalizing HIV Tat with HIV LTRs of integrated proviruses in isolated live nuclei [169], and detecting HIV IN live cells using specific immunofluorescent [170]. These studies have identified HIV proviruses or HIV IN near the nuclear membrane after import. Other studies reported HIV signal at some distance from nuclear membrane $[150,166,168]$, while real-time studies from Burdick et al. demonstrated slow movement away from NPCs [170].
Hope and coworkers have suggested studies to investigate the role of nuclear architecture, other HIV proteins (e.g., capsid), and cellular components in HIV integration [171]. Such studies may reveal useful insights into HIV replication and nuclear import, especially regarding how the processes of reverse transcription and nuclear import are coordinated. These approaches will require analysis of the primary targets of HIV, including lymphocytes and macrophages. While macrophages have comparatively large nuclei and are likely easier to analyze, new studies of lymphocytes are especially needed. Visualization approaches, including sensitive single cell technologies that can identify intranuclear location of HIV DNA within these nuclei are essential. Methods to simultaneously detect HIV provirus and HIV RNA transcription in infected lymphocytes have been reported [172]. Live cell studies are particularly useful to elucidate the dynamics of RNA expression from HIV proviruses [168-170].

Not all of the newly synthesized viral cDNA molecules, however, are successfully integrated into the host genome. In the nucleus, a subset of reverse transcripts comprise unintegrated episomal molecules that include 1- or 2-LTR circles and defective autointegrants [173]. Circular forms are not replicated as the cell divides, are diluted out upon cell replication, and do not contribute to ongoing replication. The longevity of such forms is a subject of debate. In tissue culture, circular LTR forms are lost several weeks after infection [174-176] but are stable in long term cultures of nondividing cells [176, 177]. In vivo they may persist for longer periods $[28,178]$, similar to $\mathrm{T}$ cell receptor excision DNA circles (TRECs) [179].

\section{Integration in vivo: analysis of HIV integration junction sequences}

Initial in vivo studies of proviral integration sites utilized inverse PCR to characterize HIV integration sites in CD4+ T cells from HIV infected individuals [180-182]. These studies confirmed what had been found from in vitro tissue culture systems with a preference for HIV DNA to integrate into transcriptionally active genes, usually within introns (range: 93-96\%) [180-182]. Initial longitudinal analyses revealed that identical integration sites could persist in individuals for years during therapy. However, the methods used could not determine whether this arose through clonal expansion or simply represented long-term persistence [181]. Multiple individuals were identified as having proviral integration sites in the $B A C H 2$ gene and all integrations were in the same orientation of the gene [181]. $B A C H 2$ is highly expressed in $\mathrm{B}$ lymphocytes and plays a role in the regulation of $\mathrm{B}$ cell development [183]. While expression of $B A C H 2$ has been shown in T lymphocytes in vitro [183] and in vivo [181], 
the function of $B A C H 2$ in these cells remains unknown. Further, it was not understood at the time if the enrichment of integration sites in $\mathrm{BACH} 2$ is the result of preferential integration or, rather, a selective advantage towards long-term persistence of cells that harbor integrants in $\mathrm{BACH} 2$.

New methods have been developed to detect and quantify HIV integration sites. Assays that can detect both the site of integration and the presence of clonal expansion represent a pivotal advance. Pioneering work from the Bangham laboratory inferred selective forces that shape the landscape of human $\mathrm{T}$ cell leukemia virus 1 (HTLV1) clones in vivo [184]. A high-throughput approach was developed to identify the locations of unique HTLV-1 integration sites in the host genome [185]. This method, based on random shearing and linker-mediated PCR followed by next generation paired-end sequencing, enables simultaneous mapping and quantification of unique integration sites in HTLV-1 infected T-cells [185, 186]. Integration sites from gene therapy vectors and retroviruses, including HTLV-2 [187], murine leukemia virus (MLV) [188], and recently HIV [78], have been investigated using this approach. The abundance of specific clones can be assessed by the number of unique host break points. Identical integration sites with different lengths of host sequence imply clonal expansion, whereas identical integration sites with identical lengths of host sequences are the product of PCR amplification (Fig. 3). A novel alternative approach to identify HIV proviral integration sites, the integration site loop amplification (ISLA) assay, was developed by Wagner and co-workers [80] (Fig. 4). ISLA utilizes linear amplification of proviral integration sites to increase their abundance, followed by loop formation using random decamers tailed with an HIV LTR U5-specific sequence [80]. This results in circularized amplicons containing HIV LTR sequence flanking the host genome at the site of integration, the HIV:host junction is then mapped using HIV LTR primers (Fig. 4). Both of these methods (reviewed in [41]) reduce bias since they do not rely on PCR amplification or restriction digestion both of which favor amplification of some integration sites.

Critically, these assays identify the integration junction sequence and the presence of clonal expansion. Yet, current approaches for integration site identification do not characterize the structure of the provirus located at the integration site. This is mainly due to the short amplicon constraints imposed by current next generation sequencing platforms. Integration site recovery has been insightful and has retrieved $10^{2}-10^{3}$ integration sites from 5 to 10 million PBMCs. Initial studies revealed a number of

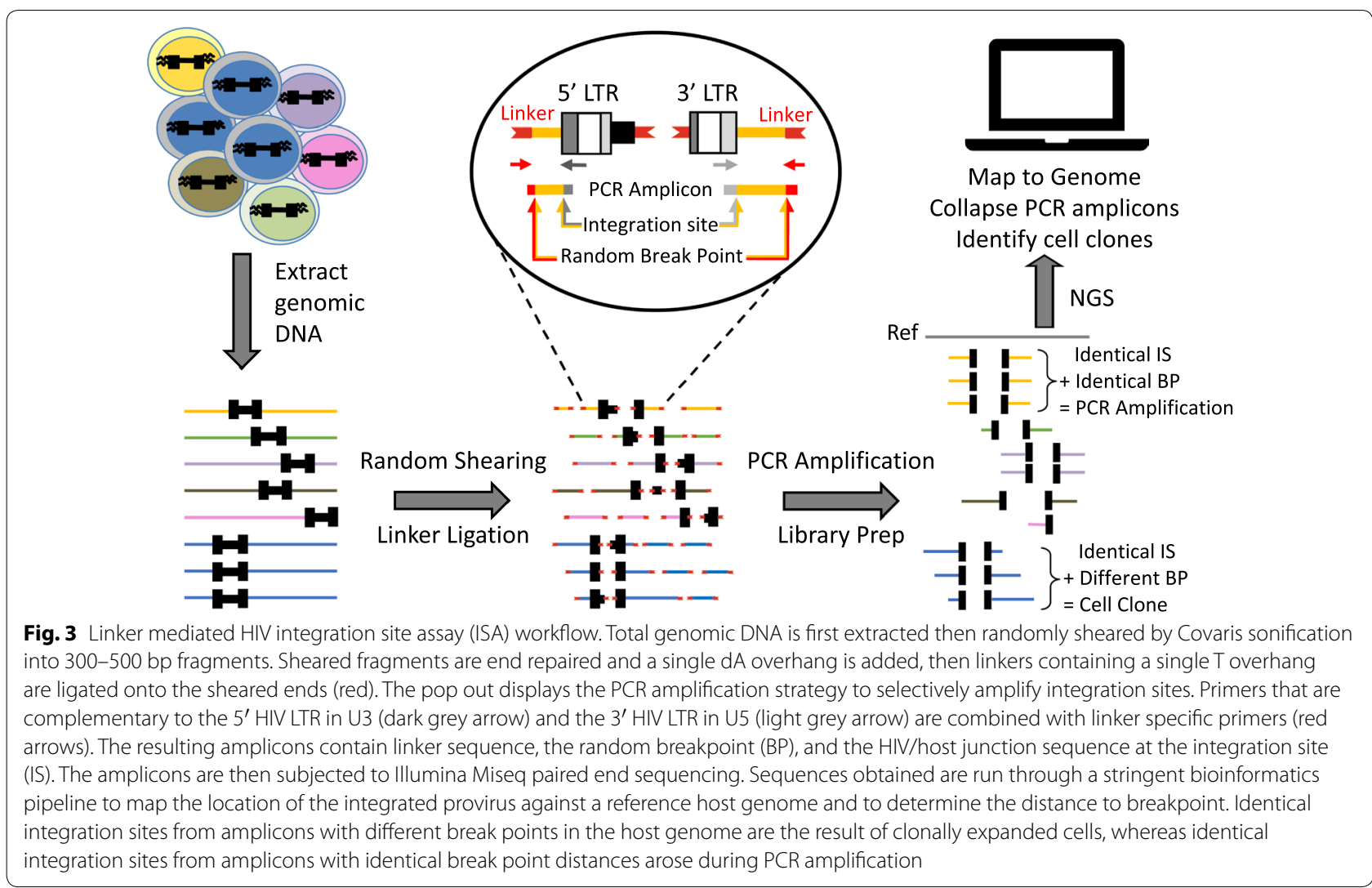




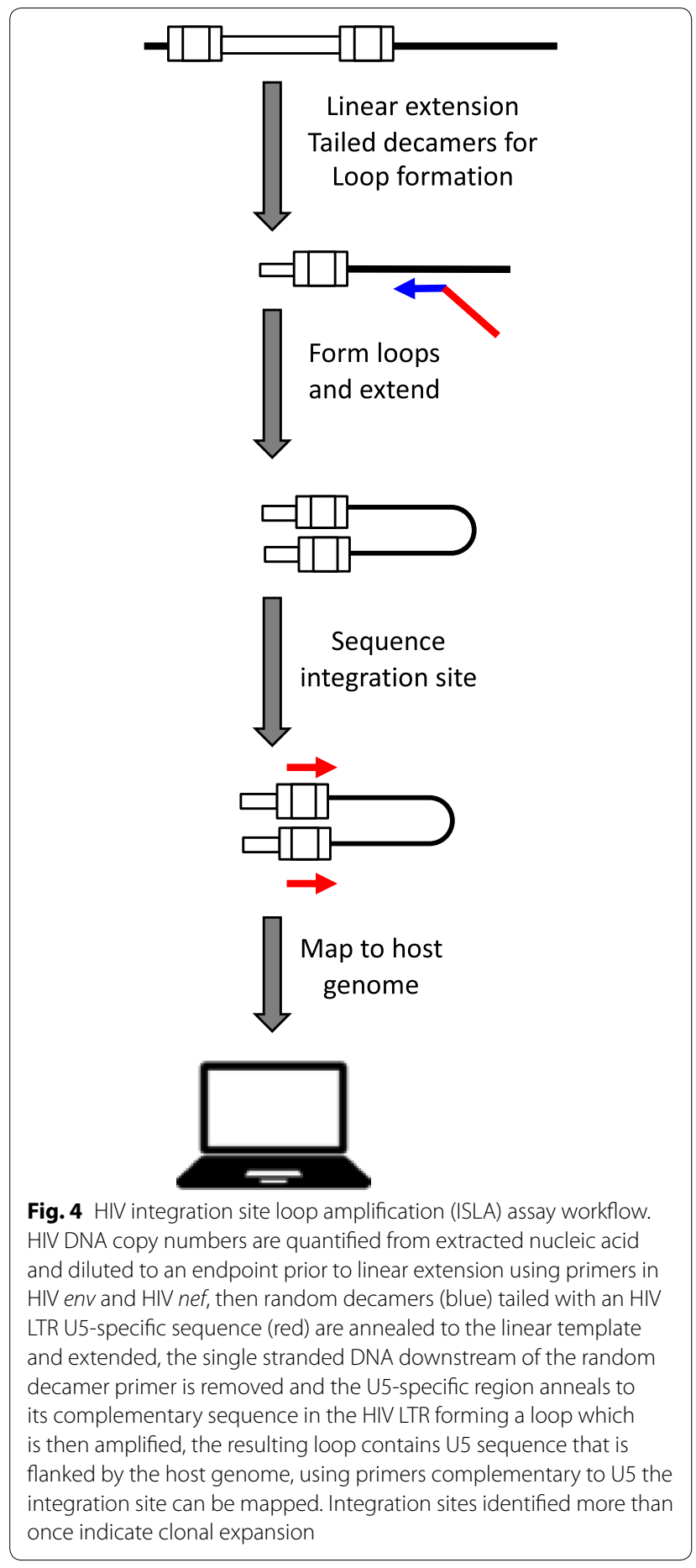

unexpected findings: HIV infected cells present after prolonged cART are frequently clonally expanded. Overall, circa $40 \%$ of all cells harboring HIV proviruses are the product of clonal expansion. As described above, the efficiency of recovery of integrated proviruses is comparatively low, as such the actual frequency of clonal expansion is likely to be much higher [78]. Moreover, Wagner et al. demonstrated that clonal expansion increased during antiretroviral therapy [80]. Longitudinal analyses revealed specific expanded clones were present over prolonged periods ( $>10$ years), demonstrating durable persistence of HIV infected cells [80].

Analysis of the distribution of integration sites using bioinformatic tools to investigate the functions of genes have revealed many proviruses were present in genes associated with cell growth $[78,80]$. The cells remaining after long-term cART were infected many years prior to their sampling. Therefore, the enrichment in genes associated with cell growth raises the strong possibility that the presence of the provirus in these genes contributes to persistence, expansion, or both.

As expected, proviruses were most frequently identified in introns, and were integrated in the same or opposite direction of host transcription, similar to those detected in in vitro infections. However, proviruses in several genes, including $B A C H 2$ and $M K L 2$, were present integrated only in the same orientation as the host gene transcription. In addition, integrations into these genes were highly restricted, and identified only in a limited region of the host gene (Introns 4 and 6 for MKL2, Introns 4 and 5 for $B A C H 2$ ) [78]. Control experiments analyzing the distribution of HIV integration sites in acute in vitro infections of HIV demonstrated that proviruses are commonly found throughout the $M K L 2$ and $B A C H 2$ genes [78]. However, the striking finding that in in vivo experiments they were only present in the same orientation as host gene transcription after prolonged cART suggested that proviruses present in intron 4 or 6 provided a direct selective advantage that contributed to persistence, and expansion [78]. Proviruses present in other parts of these genes were not detected after prolonged ART presumably because they did not have a selective advantage.

Megakaryoblastic Leukemia (MKL)/Myocardin-Like Protein 2 (MKL2) is a phosphorylation mediated transcriptional activator that modulates the transcription of many cellular early genes by regulating the transcription factor serum response factor (SRF). SRF is a reported oncogene involved in promoting proliferation of mammary and hepatocellular adenocarcinomas [189, 190]. Fusions of MKL2 and C11orf95 have been frequently identified in choroid lipomas, suggesting a role in growth and expansion of these neoplasms [191]. MKL2 fusion with RREB1 has been described in oropharyngeal sarcoma [192]. MKL2 has also been implicated in development of hippocampal neurons [193] and muscle [194, 195]. However, the precise role of MKL2 in T cell homeostasis has not been extensively studied.

The transcription regulator protein $\mathrm{BACH} 2$ is a member of the basic leucine zipper transcription factor 
family that typically associates with Maf proteins to permit the binding of a $\mathrm{BACH} 2-\mathrm{Maf}$ heterodimer to specific DNA promoter recognition sites (reviewed by Igarashi et al. [196]). BACH2 functions in normal B cell development [197], is frequently deleted in B cell tumors [183, 198], and reduced levels of $\mathrm{BACH} 2$ have been associated with poor outcome in response to chemotherapy [199]. In addition, aggressive lymphomas containing IGHC $\delta$-BACH2 fusion protein have been identified [200]. More recently, BACH2 has been demonstrated to have critical roles in $\mathrm{T}$ cell homeostasis [201-203]. As reviewed by Richer et al. [204], $\mathrm{BACH} 2$ may participate in regulating development during $\mathrm{T}$ cell differentiation, especially of T-regulatory and $\mathrm{T}$ effector lineages. BACH2 may also contribute to maintaining cell quiescence by preventing differentiation into effector memory cells [201, 202]. It is not known how HIV integration affects $B A C H 2$ expression.

In infected cells, integrations into $B A C H 2$ were limited to introns 4 and 5 , which are in the $5^{\prime}$ untranslated region several thousand nucleotides upstream of the $B A C H 2$ start codon [78]. This suggests the possibility that transcription may be initiated from the proviral LTR promoter and not from the authentic $B A C H 2$ promoter. Indeed, Cesana et al. recently reported the detection of chimeric transcripts encoding HIVLTR-BACH2 in a substantial number of HIV infected patients undergoing antiretroviral therapy [205]. These transcripts consists of HIV $5^{\prime}$ untranslated sequence to the major splice donor from HIV spliced to exon 5 of $B A C H 2$. It is not yet clear whether these transcripts are initiated at +1 of HIV or represent read-through transcripts of $B A C H 2$ intron 4 [205]. These data demonstrate that chimeric host-HIV RNA is common, and increased expression of $\mathrm{BACH} 2$ may influence persistence and clonal expansion. Cesana et al. also demonstrated evidence of chimeric HIV transcripts with STAT5B, a transcription factor central to $T$ cell activation, in PBMCs from a substantial number of infected individuals undergoing antiretroviral therapy [205]. Integrations into STAT5B were identified in a number of patients, but without significant orientation specificity [78]. Additional study of these specific examples of HIV integration is needed. Although integrations into these genes has been demonstrated, only limited sequence information of the HIV:host junction has been obtained and the structure of the entire proviruses in $B A C H 2, M K L 2$ and STAT5B remains uncertain. The data of Cesana et al. indicate that at least the R, U5, and $5^{\prime}$ untranslated HIV sequence to the major splice donor is present, but the remainder of the provirus structure is not known. It should be emphasized that although integrants in these genes were found in numerous HIV infected individuals, their actual abundance in PBMC populations is quite low, on the order of 1-10 copies/ million PBMC, complicating amplification and characterization of integrated proviruses.

The limits and consequences of clonal expansion remain poorly understood. Clonal expansion is detected during long-term cART, although total HIV DNA levels remain relatively constant. Thus, clonal expansions occur but do not appear to increase the abundance of virus infected cells. Control mechanisms that permit clonal expansion but restrict the number of HIV infected cells are not known. Similarly, HIV integration has not been associated, as yet, with malignant transformation of HIV infected cells. In fact, CD4+ T cell leukemia and lymphoma is distinctly uncommon in HIV infected individuals [206, 207]. It is likely that clonal amplification, even to the large abundance as we and others have identified [78, 80, 208], is insufficient for malignant transformation. Of note, clonal expansions of $\mathrm{T}$ cells are present in individuals infected with other human retroviruses, including both HTLV-1 and HTLV-2 [185, 187]. However, hematologic malignancies are only detected in a minority of HTLV-1 infections, suggesting that malignant transformation is likely due to additional requirements [209].

Advances in next generation sequencing approaches have enabled in depth analyses of proviral integration sites from PBMCs of HIV infected individuals on cART $[78,80,208]$. These methodologies allow quantification of multiple identical integration sites and the ability to identify clonal expansion. Since the probability of HIV integration into the exact same location in the host genome more than once is vanishingly small, clonal expansion can be defined as a population of cells derived from cell division that harbor a provirus integrated into the exact same location in the host genome. Analyses of these integration sites show clonally expanded HIV infected CD4 $+\mathrm{T}$ cells exist after years on therapy suggesting that clonal expansion is a major mechanism that enables HIV persistence despite the success of cART [78]. Yet, current approaches for integration site identification do not characterize the structure of the provirus located at the integration site. This is mainly due to the short amplicon constraints imposed by these sequencing platforms. Therefore, novel approaches to map integration sites and provirus structure will aid in understanding long-term HIV persistence and reservoir maintenance. Characterization of HIV integrant structures will be useful for constructing model systems in which proviruses can be specifically targeted, for instance with CRISPR/ Cas, to investigate the effects of proviral integration on cell growth and differentiation. Further detailed analyses of integration site distribution in vivo will aid in the study of cellular functions in the context of HIV infection. 
As integration sites are identified by various research groups, they should be compiled and made available for analyses through established public databases in order to robustly advance this key area of inquiry [210].

\section{The role of clonal expansion in maintaining HIV persistence}

Clonal expansion of HIV infected cells can persist in patients for over 10 years on suppressive cART [78, 80, 208]. Early studies found populations of virus with identical sequences emerge in the plasma of HIV infected individuals who were suppressed for years on cART suggesting that highly expanded cell clones gave rise to persistent viremia [211, 212]. The discovery of identical HIV sequences from clearly defective or APOBEC hypermutated proviruses indicated that the only way the virus could arise was through clonal expansion [213]. A mathematical model predicted that clonal expansion and contraction of latently infected cells upon sporadic antigen stimulation can generate persistent low level viremia and lead to intermittent viral blips [214]. Although experimental data is needed to confirm these findings, this model also indicates that a fraction of activated $\mathrm{T}$ cells can revert back to the latent state thereby providing a mechanism to continually replenish the latent reservoir [214].

The majority of HIV DNA decay occurs within the first year on CART, after which it remains relatively stable in participants treated during chronic infection [28]. Meanwhile, the reservoir of replication competent proviruses, as measured with qVOA, decays minimally [26]. Yet, the frequency of clonally expanded cells harboring integrated proviruses increase over time [80]. Therefore, the overall composition of the reservoir is dynamic and changes over time despite suppressive cART. For instance, although the majority of integrated proviruses are defective or deleted [23], some can still be transcribed and produce proteins which can be targeted by CTL for killing [24, 25]. Moreover, clonal expansion of cells harboring integrated proviruses can occur through homeostatic forces, as a consequence of the integration site, or by antigen stimulation $[78,79]$.

Homeostatic proliferation is a mechanism for $\mathrm{T}$ cell division that may play a role in maintaining the reservoir over time. Previous studies have implicated interleukin 7 (IL-7) in the homeostatic regulation of the $\mathrm{T}$ cell pool [215]. IL-7 is produced by non-hematopoietic cells and is involved in thymocyte development and survival [216]. During chronic infection, CD4+ $\mathrm{T}$ cell depletion is associated with increased levels of proliferation through elevated levels of IL-7 and ultimately larger reservoir size, indicating that IL-7 is responsible for the persistence of latently infected cells by promoting homeostatic proliferation [217]. IL-7 induced proliferation can occur without reactivation of the virus in an in vitro model of HIV latency [89] and in vivo [88]. Taken together these studies suggest $\mathrm{T}$ cell division of HIV infected cells permits HIV persistence in the absence of ongoing cycles of viral replication.

Integration site driven clonal expansion is believed to occur infrequently and is the result of a nearly random integration site selection process. Multiple individuals have been identified as having proviral integrations enriched in genes associated with cell growth some of which were found to be clonally expanded [78, 80]. These findings raises the possibility that the presence of the provirus within the oncogene contributes to the ability of the cell to persist or to undergo clonal expansion in an integration site driven manner. The frequency of integration site driven clonal expansion and the mechanisms that govern these cell clones are still under active investigation.

Identifying clonal populations containing replicationcompetent HIV proviruses is challenging because these cells are generally rare, and are present in large populations of cells containing defective proviruses. In vivo, most HIV infected cells persisting for prolonged periods on ART contain defective proviruses [23, 111]. The initial finding that many cells present after prolonged cART are the products of clonal expansion $[78,80]$ was thought to reflect clonal expansion of defective, but not replication competent proviruses [208]. Clonal populations harboring defective HIV can contribute to ongoing immune activation, which may enable persistence $[24,25,111]$ but these populations cannot give rise to rebounding viremia upon treatment interruption and therefore do not contribute to the 'true' HIV reservoir. Initial analyses of plasma HIV during prolonged antiretroviral therapy revealed the presence of populations of identical sequences, suggesting these variants were the product of clonal expansion. Detailed analyses of one example of predominant plasma clone [79] led to identification of the integration site of the provirus responsible for the clone and that the provirus was replication competent. The provirus has a unique integration site, but is present in a region that has not been mapped to a unique location. The integrant was designated AMBI-1 (ambiguous) to reflect that the location in the human genome is ambiguous [79]. Amplification from the known integrant was determined to be replication competent in in vitro infections, and the identical virus could also be repeatedly recovered in vitro from endpoint diluted PBMC cultures. Cells harboring the AMBI-1 integrant were found to be widely anatomically distributed but enriched in cancer metastases indicating that the clone expanded in response to the 
cancer antigen [79]. These data demonstrated that clonally expanded populations can contain infectious HIV, and therefore represent a relevant reservoir for HIV during cART.

The finding of a clonally expanded population with infectious HIV was unexpected as HIV is frequently cytolytic and encodes an accessory protein $(\mathrm{Vpr})$ which can arrest the cell cycle [218]. It is possible that cell division and virus production are compartmentalized, and do not take place concurrently. Recent studies have shown that populations of clonally expanded cells persist on cART and only a fraction of cells within the clone are transcriptionally active $[219,229]$. Furthermore, upon treatment interruption, transcriptionally active cells ultimately gave rise to rebounding viremia [220]. Taken together, these studies suggest that clonally expanded cells containing replication competent proviruses comprise a portion of the true HIV reservoir and that a proportion of transcriptionally active cells within the clone contribute to low level persistent viremia and ultimately rebounding virus upon treatment interruption. A critical understanding of these populations, their HIV RNA expression levels, and mechanisms which govern their active or latent states are is crucial for targeting eradication efforts.

The frequency of clonally expanded cells that harbor replication competent proviruses, such as AMBI-1, is not known, although recent data indicate that they may be relatively common [221-223]. Unequivocal identification of such proviruses is labor intensive and technically complex, but their characterization will yield key information regarding the requirements for persistence during therapy. Such proviruses represent a substantial obstacle to HIV cure. Furthermore, the dynamics of clonal expansion of cells containing replication competent proviruses is not well described and may be shaped by immune selection pressures. Recently it was found that these clones can wax and wane or persist steadily in vivo for years [224]. The mechanisms by which these cells can proliferate without viral reactivation to maintain the reservoir despite therapy poses a major obstacle towards an HIV cure. Shock and kill strategies aimed at HIV eradication will need to reactivate quiescent cells without inducing cell replication, which could result in unintended expansion of a cellular reservoir of infected cells. A number of such agents capable of activating cells without inducing cell division are under investigation. Analysis of proviral integration sites as part of the analytic approach to HIV eradication strategies will be a useful adjunct to current reservoir studies. Current integration site assays are, as described above, not highly efficient, and sensitivity will likely need to be optimized to detect low level clonal expansion. Taken together, these findings suggests that both active CTL selection pressures and passive clonal expansion mechanisms can drive the remodeling of the HIV reservoir over time. Finally, clonal expansion provides multiple targets to decrease the probability that a cell with an intact provirus will be eliminated precluding eradication strategies.

\section{Characterizing clonal expansion in the setting of eradication strategies}

Several strategies aimed at eradicating the latent HIV reservoir have been employed. These include ART regime intensification, gene therapy, stem cell transplantation, therapeutic vaccines, and latency reversal agents (LRAs). LRAs are being used in a number of studies to potentially eliminate HIV through inducing reactivation of quiescent $\mathrm{T}$ cells in the hopes that these reactivated cells will undergo cell death. The original concept of purging the latent reservoir by reversing latency through activation of latently infected cells was implemented using interleukin 2 (IL-2) and T cell activators such as anti-CD3 antibodies (OKT3) [225, 226]. From these initial studies, it was clear that activation of latently infected $\mathrm{T}$ cells could be achieved and may enable purging of the reservoir, however, other compounds to reverse latency with reduced toxicity were needed.

Characterizing clonal expansion in the setting of eradication strategies such as 'shock and kill' sheds critical new light on the true structure of the HIV reservoir and whether that structure has been altered with treatment. The majority of current LRA strategies have utilized histone deacetylase inhibitors (HDACi). Even though some LRA strategies have successfully reversed latency in patients undergoing suppressed cART, measured by increased HIV transcription and virion production, no strategy has led to a decrease in the frequency of latently infected cells to date (reviewed by Bashiri et al. [227]). The inability of current LRA strategies to reduce the latent reservoir size can be attributed to insufficient host immune responses after latency reversal, an insufficient magnitude of latency reversal, or both. Therefore, new strategies that have higher specificity and potency to efficiently reverse latency may be needed in combination with therapies aimed at boosting the host immune response to sufficiently clear virus producing cells [228].

It is possible that LRA treatment can instead promote clonal expansion and thereby increase the reservoir size preventing elimination. IL-7 therapy has been administered to HIV-infected individuals to induce an increase in naïve and memory T-cell numbers [86, 87]. Yet, in vitro and in vivo studies predict that IL-7 administration would lead to an expansion of T-cells including HIV infected T-cells and thereby have a potential to increase the HIV reservoir without reactivating the virus $[88,89]$. Characterization of individual HIV integration sites will 
identify which integrants were reactivated, eliminated, or expanded during latency reversal.

\section{Conclusions}

Integration is a critical and, as yet, irreversible step in HIV replication that enables the persistence of HIV in a reservoir of long-lived cells despite suppressive antiretroviral therapy. The reservoir of infected cells harboring inducible full length replication competent proviruses is a major barrier to an HIV cure. Understanding the mechanisms of reservoir maintenance may provide novel targets for therapeutic interventions. Clonal expansion of HIV infected cells is a key mechanism for maintenance of the reservoir.

Current assays to measure and characterize integration sites are costly, time consuming, and labor intensive. Therefore, novel assays to measure clonal expansion are of key interest. Alternatively, sequences can be obtained from individual HIV proviruses through endpoint dilution and PCR amplification [229]. While it is impossible to determine whether two proviruses are identical without comparing individual full length sequences, which are prohibitively expensive to generate at present, a surrogate to predict clonal expansion can be calculated with the clonal prediction score [230]. This metric considers the length of the amplicon and the intra-patient genetic diversity to determine the likelihood that individual identical sequences are the result of clonal expansion. This tool, while not definitive, may provide a measure to assess clonal expansion in the absence of intensive integration site analyses.

Methods to characterize the provirus sequence and structure as it is integrated into particular locations in the host genome need further development. For example, the generation of full length HIV genome amplicons that cross into the host at the HIV-host junction could provide insights into the abundance of replication competent proviruses in clonal populations, as well as the biological relevance of enriched integration sites. Extensive sequence data will enable phylogenetic analyses to elucidate timing of proviral integration as well as estimates of total population sizes within the host. Detailed assessments of intact versus defective and deleted proviruses can characterize the composition of HIV reservoirs over time and linking these data to the integration site may reveal novel immune selective pressures that eliminate or favor certain proviral structures over time.

Distinguishing how proviral structure influences transcription and RNA splicing within individual host genes may reveal alternative splice variants and their biological function in HIV persistence. For instance, it has been shown that HIV and lentiviral vectors may induce aberrant RNA splicing mechanisms resulting in the production of chimeric transcripts containing HIV sequence fused to cellular exon sequences [231-233]. Furthermore, it has been shown that lentiviral vectors with active LTRs can induce neoplastic transformation through the activation of cancer-related genes via promoter insertion [234]. In addition, chimeric HIV/BACH2 transcripts were found in several individuals (34\%) with HIV integrations in the $B A C H 2$ gene, indicating that expression of these transcripts could favor the persistence of those cells [205]. Likewise studying the three-dimensional (3D) chromatin structure of integrated proviruses may provide insights into mechanisms influencing the location of integration as well as the $3 \mathrm{D}$ interactions between integrated proviruses and host genes.

Finally, elucidating the timing of clonal expansion may provide novel strategies to limit the size of the reservoir in HIV infected individuals. For instance, the extent of clonal expansion prior to the initiation of treatment and the effects of early treatment on the pool of infected, clonally expanded cells is of great interest. Understanding whether antiretroviral treatment permits clonal expansion or rather reveals the infected cell clones that were present prior to and upon treatment initiation is pivotal. Such studies require the development of deeper and more comprehensive integration site mapping techniques and the examination of unique cohorts of individuals identified during acute HIV infection. Characterizing clonal expansion in the setting of immune recovery is needed to determine whether the increase in CD4 cell number over time during therapy is reflected in clonally expanded populations. Gaining a deeper understanding of clonal expansion of HIV infected cells as a mechanism of HIV persistence despite cART will provide needed strategies for reservoir elimination and ultimately HIV eradication.

\begin{abstract}
Abbreviations
CART: combination antiretroviral therapy; PBMC: peripheral blood mononuclear cell; GALT: gut-associated lymphoid tissue; CTL: cytotoxic T lymphocyte; APOBEC: apolipoprotein B mRNA editing enzyme; ddPCR: droplet digital PCR; qVOA: quantitative viral outgrowth assay; BrdU: bromodeoxyuridine; IN: HIV integrase; CA: HIV capsid; RT: reverse transcriptase; LTR: long terminal repeat; PIC: pre-integration complex; ALLINIs: allosteric integrase inhibitors; BAF1: barrier to autointegration factor 1; HMG: high mobility group; LAP2a: laminaassociated polypeptide 2a; TNPO3: karopherin transportin SR2; LEDGF/p75: lens epithelial-derived growth factor; TREC: T cell receptor excision DNA circles; ISLA: integration site loop amplification; ISA: integration site assay; AMBI-1: ambiguous integrant 1; MKL2: megakaryoblastic leukemia/myocardin-like protein 2; SRF: serum response factor; STAT5B: signal transducer and activator of transcription 5B; BACH2: BTB domain and CNC homolog 2.
\end{abstract}

Authors' contributions

EMA and FM wrote the review. All authors read and approved the final manuscript.

Acknowledgements

Not applicable. 


\section{Competing interests}

The authors declare they have no competing interests.

\section{Availability of data and materials}

All data reviewed in this manuscript are included in the respective referenced publications.

\section{Consent for publication}

Not applicable.

\section{Ethics approval and consent to participate}

Not applicable.

\section{Funding}

This work was supported by Federal funds from the National Cancer Institute, an $\mathrm{NIH}$ Bench to Bedside award (FM), and by funds from the National Cancer Institute under Contract No HSSN261200800001E.

\section{Publisher's Note}

Springer Nature remains neutral with regard to jurisdictional claims in published maps and institutional affiliations.

Received: 29 June 2018 Accepted: 15 September 2018

Published online: 23 October 2018

\section{References}

1. Palmer S, Maldarelli F, Wiegand A, Bernstein B, Hanna GJ, Brun SC, Kempf DJ, Mellors JW, Coffin JM, King MS. Low-level viremia persists for at least 7 years in patients on suppressive antiretroviral therapy. Proc Natl Acad Sci USA. 2008;105(10):3879-84.

2. Palella FJ Jr, Delaney KM, Moorman AC, Loveless MO, Fuhrer J, Satten GA, Aschman DJ, Holmberg SD. Declining morbidity and mortality among patients with advanced human immunodeficiency virus infection. HIV outpatient study investigators. N Engl J Med. 1998;338(13):853-60.

3. Palella FJ Jr, Baker RK, Moorman AC, Chmiel JS, Wood KC, Brooks JT, Holmberg SD, Investigators HIVOS. Mortality in the highly active antiretroviral therapy era: changing causes of death and disease in the HIV outpatient study. J Acquir Immune Defic Syndr. 2006;43(1):27-34

4. d'Arminio Monforte A, Sabin CA, Phillips A, Sterne J, May M, Justice A, Dabis F, Grabar S, Ledergerber B, Gill J, Reiss P, Egger M, Antiretroviral Therapy Cohort $C$. The changing incidence of AIDS events in patients receiving highly active antiretroviral therapy. Arch Intern Med. 2005:165(4):416-23.

5. Mocroft A, Vella S, Benfield TL, Chiesi A, Miller V, Gargalianos P, d'Arminio Monforte A, Yust I, Bruun JN, Phillips AN, Lundgren JD. Changing patterns of mortality across Europe in patients infected with HIV-1. EuroSIDA Study Group. Lancet. 1998;352(9142):1725-30.

6. Antiretroviral Therapy Cohort C. Causes of death in HIV-1-infected patients treated with antiretroviral therapy, 1996-2006: collaborative analysis of 13 HIV cohort studies. Clin Infect Dis. 2010;50(10):1387-96.

7. Weber R, Ruppik M, Rickenbach M, Spoerri A, Furrer H, Battegay M, Cavassini M, Calmy A, Bernasconi E, Schmid P, Flepp M, Kowalska J, Ledergerber B, Swiss HIVCS. Decreasing mortality and changing patterns of causes of death in the Swiss HIV Cohort Study. HIV Med. 2013;14(4):195-207

8. WyI V, Gianella S, Fischer M, Niederoest B, Kuster H, Battegay M, Bernasconi E, Cavassini M, Rauch A, Hirschel B, Vernazza P, Weber R, Joos B, Gunthard HF, Swiss HIVCS-S. Early antiretroviral therapy during primary HIV-1 infection results in a transient reduction of the viral setpoint upon treatment interruption. PLOS ONE. 2011;6(11):e27463.

9. Yerly S, Gunthard HF, Fagard C, Joos B, Perneger TV, Hirschel B, Perrin L, Swiss HIVCS. Proviral HIV-DNA predicts viral rebound and viral setpoint after structured treatment interruptions. AIDS. 2004;18(14):1951-3.

10. Davey RT Jr, Bhat N, Yoder C, Chun TW, Metcalf JA, Dewar R, Natarajan V, Lempicki RA, Adelsberger JW, Miller KD, Kovacs JA, Polis MA, Walker RE, Falloon J, Masur H, Gee D, Baseler M, Dimitrov DS, Fauci AS, Lane HC. HIV-1 and T cell dynamics after interruption of highly active antiretroviral therapy (HAART) in patients with a history of sustained viral suppression. Proc Natl Acad Sci USA. 1999;96(26):15109-14.

11. IAS, Deeks SG, Autran B, Berkhout B, Benkirane M, Cairns S, Chomont N, Chun TW, Churchill M, Di Mascio M, Katlama C, Lafeuillade A, Landay A, Lederman M, Lewin SR, Maldarelli F, Margolis D, Markowitz M, MartinezPicado J, Mullins Jl, Mellors J, Moreno S, O'Doherty U, Palmer S, Penicaud MC, Peterlin M, Poli G, Routy JP, Rouzioux C, Silvestri G, Stevenson M, Telenti A, Van Lint C, Verdin E, Woolfrey A, Zaia J, Barre-Sinoussi F. Towards an HIV cure: a global scientific strategy. Nat Rev Immunol. 2012;12(8):607-14.

12. Joos B, Fischer M, Kuster H, Pillai SK, Wong JK, Boni J, Hirschel B, Weber R, Trkola A, Gunthard HF, Swiss HIVCS. HIV rebounds from latently infected cells, rather than from continuing low-level replication. Proc Natl Acad Sci USA. 2008;105(43):16725-30.

13. Serrao E, Ballandras-Colas A, Cherepanov P, Maertens GN, Engelman AN Key determinants of target DNA recognition by retroviral intasomes. Retrovirology. 2015;12:39.

14. Wu X, Li Y, Crise B, Burgess SM, Munroe DJ. Weak palindromic consensus sequences are a common feature found at the integration target sites of many retroviruses. J Virol. 2005:79(8):5211-4.

15. Shan L, Deng K, Gao H, Xing S, Capoferri AA, Durand CM, Rabi SA, Laird GM, Kim M, Hosmane NN, Yang HC, Zhang H, Margolick JB, Li L, Cai W, Ke R, Flavell RA, Siliciano JD, Siliciano RF. Transcriptional reprogramming during effector-to-memory transition renders CD4(+) T cells permissive for latent HIV-1 infection. Immunity. 2017:47(4):766-75 e3.

16. Zack JA, Kim SG, Vatakis DN. HIV restriction in quiescent CD4(+) T cells. Retrovirology. 2013;10:37.

17. Pace MJ, Graf EH, Agosto LM, Mexas AM, Male F, Brady T, Bushman FD, O'Doherty U. Directly infected resting CD4+ T cells can produce HIV Gag without spreading infection in a model of HIV latency. PLoS Pathog. 2012;8(7):e1002818

18. Chavez L, Calvanese V, Verdin E. HIV latency is established directly and early in both resting and activated primary CD4 T cells. PLoS Pathog. 2015;11(6):e1004955

19. Finzi D, Blankson J, Siliciano JD, Margolick JB, Chadwick K, Pierson T, Smith K, Lisziewicz J, Lori F, Flexner C, Quinn TC, Chaisson RE, Rosenberg E, Walker B, Gange S, Gallant J, Siliciano RF. Latent infection of CD4+ T cells provides a mechanism for lifelong persistence of HIV-1, even in patients on effective combination therapy. Nat Med. 1999;5(5):512-7.

20. Chun TW, Engel D, Berrey MM, Shea T, Corey L, Fauci AS. Early establishment of a pool of latently infected, resting CD4(+) T cells during primary HIV-1 infection. Proc Natl Acad Sci USA. 1998:95(15):8869-73.

21. Finzi D, Hermankova M, Pierson T, Carruth LM, Buck C, Chaisson RE, Quinn TC, Chadwick K, Margolick J, Brookmeyer R, Gallant J, Markowitz $M, H o$ DD, Richman DD, Siliciano RF. Identification of a reservoir for HIV-1 in patients on highly active antiretroviral therapy. Science. 1997;278(5341):1295-300.

22. Wong JK, Hezareh M, Gunthard HF, Havlir DV, Ignacio CC, Spina CA, Richman DD. Recovery of replication-competent HIV despite prolonged suppression of plasma viremia. Science. 1997;278(5341):1291-5.

23. Ho YC, Shan L, Hosmane NN, Wang J, Laskey SB, Rosenbloom DI, Lai J, Blankson JN, Siliciano JD, Siliciano RF. Replication-competent noninduced proviruses in the latent reservoir increase barrier to HIV-1 cure. Cell. 2013;155(3):540-51.

24. Imamichi H, Dewar RL, Adelsberger JW, Rehm CA, O'Doherty U, Paxinos EE, Fauci AS, Lane HC. Defective HIV-1 proviruses produce novel protein-coding RNA species in HIV-infected patients on combination antiretroviral therapy. Proc Natl Acad Sci USA. 2016;113(31):8783-8.

25. Pollack RA, Jones RB, Pertea M, Bruner KM, Martin AR, Thomas AS, Capoferri AA, Beg SA, Huang SH, Karandish S, Hao H, Halper-Stromberg E, Yong PC, Kovacs C, Benko E, Siliciano RF, Ho YC. Defective HIV-1 proviruses are expressed and can be recognized by cytotoxic $T$ lymphocytes, which shape the proviral landscape. Cell Host Microbe. 2017;21(4):494506 e4.

26. Siliciano JD, Kajdas J, Finzi D, Quinn TC, Chadwick K, Margolick JB, Kovacs C, Gange SJ, Siliciano RF. Long-term follow-up studies confirm the stability of the latent reservoir for HIV-1 in resting CD4+ T cells. Nat Med. 2003;9(6):727-8.

27. Crooks AM, Bateson R, Cope AB, Dahl NP, Griggs MK, Kuruc JD, Gay CL, Eron JJ, Margolis DM, Bosch RJ, Archin NM. Precise quantitation of the 
latent HIV-1 reservoir: implications for eradication strategies. J Infect Dis. 2015;212(9):1361-5.

28. Besson GJ, Lalama CM, Bosch RJ, Gandhi RT, Bedison MA, Aga E, Riddler SA, McMahon DK, Hong F, Mellors JW. HIV-1 DNA decay dynamics in blood during more than a decade of suppressive antiretroviral therapy. Clin Infect Dis. 2014;59(9):1312-21.

29. Eriksson S, Graf EH, Dahl V, Strain MC, Yukl SA, Lysenko ES, Bosch RJ, Lai J, Chioma S, Emad F, Abdel-Mohsen M, Hoh R, Hecht F, Hunt P, Somsouk M, Wong J, Johnston R, Siliciano RF, Richman DD, O'Doherty U, Palmer S, Deeks SG, Siliciano JD. Comparative analysis of measures of viral reservoirs in HIV-1 eradication studies. PLoS Pathog. 2013;9(2):e1003174.

30. Murray AJ, Kwon KJ, Farber DL, Siliciano RF. The latent reservoir for HIV1: how immunologic memory and clonal expansion contribute to HIV-1 persistence. J Immunol. 2016;197(2):407-17.

31. Badley AD, Sainski A, Wightman F, Lewin SR. Altering cell death pathways as an approach to cure HIV infection. Cell Death Dis. 2013;4:e718.

32. Hutter G, Nowak D, Mossner M, Ganepola S, Mussig A, Allers K, Schneider T, Hofmann J, Kucherer C, Blau O, Blau IW, Hofmann WK, Thiel E. Long-term control of HIV by CCR5 Delta32/Delta32 stem-cell transplantation. N Engl J Med. 2009;360(7):692-8.

33. Yukl SA, Boritz E, Busch M, Bentsen C, Chun TW, Douek D, Eisele E, Haase A, Ho YC, Hutter G, Justement JS, Keating S, Lee TH, Li P, Murray D, Palmer S, Pilcher C, Pillai S, Price RW, Rothenberger M, Schacker T, Siliciano J, Siliciano R, Sinclair E, Strain M, Wong J, Richman D, Deeks SG. Challenges in detecting HIV persistence during potentially curative interventions: a study of the Berlin patient. PLoS Pathog. 2013;9(5):e1003347.

34. Frange $P$, Faye A, Avettand-Fenoel V, Bellaton E, Descamps D, Angin M, David A, Caillat-Zucman S, Peytavin G, Dollfus C, Le Chenadec J, Warszawski J, Rouzioux C, Saez-Cirion A, Cohort AE-CP, the AEPVsg. HIV-1 virological remission lasting more than 12 years after interruption of early antiretroviral therapy in a perinatally infected teenager enrolled in the French ANRS EPF-CO10 paediatric cohort: a case report. Lancet HIV. 2016;3(1):e49-54.

35. Maggiolo F, Di Filippo E, Comi L, Callegaro A. Post treatment controllers after treatment interruption in chronically HIV infected patients. AIDS. 2018;32(5): 623-28.

36. Saez-Cirion A, Bacchus C, Hocqueloux L, Avettand-Fenoel V, Girault I, Lecuroux C, Potard V, Versmisse P, Melard A, PrazuckT, Descours B, Guergnon J, Viard JP, Boufassa F, Lambotte O, Goujard C, Meyer L, Costagliola D, Venet A, Pancino G, Autran B, Rouzioux C, Group AVS. Posttreatment HIV-1 controllers with a long-term virological remission after the interruption of early initiated antiretroviral therapy ANRS VISCONTI Study. PLoS Pathog. 2013;9(3):e1003211.

37. Stohr W, Fidler S, McClure M, Weber J, Cooper D, Ramjee G, Kaleebu P, Tambussi G, Schechter M, Babiker A, Phillips RE, Porter K, Frater J. Duration of HIV-1 viral suppression on cessation of antiretroviral therapy in primary infection correlates with time on therapy. PLOS ONE. 2013;8(10):e78287.

38. Violari A, Cotton M, Kuhn L, Schramm D, Paximadis M, Loubser S, Shalekoff S, de Costa Dias B, Otwombe A, Liberty A, McIntyre J, Babiker A, Gibb D, Tiemessen C. Viral and host characteristics of a child with perinatal HIV-1 following a prolonged period after ART cessation in the CHER trial. In 9th IAS conference on HIV science; Paris, France; 2017.

39. Craigie R, Bushman FD. HIV DNA integration. Cold Spring Harb Perspect Med. 2012;2(7):a006890

40. Hazuda DJ. HIV integrase as a target for antiretroviral therapy. Curr Opin HIV AIDS. 2012;7(5):383-9.

41. Maldarelli F. HIV-infected cells are frequently clonally expanded after prolonged antiretroviral therapy: implications for HIV persistence. J Virus Erad. 2015;1 (4):237-44.

42. Maldarelli F. The role of HIV integration in viral persistence: no more whistling past the proviral graveyard. J Clin Invest. 2016;126(2):438-47.

43. Engelman A, Cherepanov P. Retroviral integrase structure and DNA recombination mechanism. Microbiol Spectr. 2014;2(6):1-22.

44. Wong JK, YukI SA. Tissue reservoirs of HIV. Curr. Opin HIV AIDS. 2016;11(4):362-70.

45. Perelson AS, Neumann AU, Markowitz M, Leonard JM, Ho DD. HIV-1 dynamics in vivo: virion clearance rate, infected cell life-span, and viral generation time. Science. 1996;271(5255):1582-6.
46. Chun TW, Stuyver L, Mizell SB, Ehler LA, Mican JA, Baseler M, Lloyd AL, Nowak MA, Fauci AS. Presence of an inducible HIV-1 latent reservoir during highly active antiretroviral therapy. Proc Natl Acad Sci USA. 1997;94(24):13193-7.

47. Fritsch RD, Shen X, Sims GP, Hathcock KS, Hodes RJ, Lipsky PE. Stepwise differentiation of CD4 memory T cells defined by expression of CCR7 and CD27. J Immunol. 2005;175(10):6489-97.

48. Sallusto F, Geginat J, Lanzavecchia A. Central memory and effector memory $T$ cell subsets: function, generation, and maintenance. Annu Rev Immunol. 2004;22:745-63.

49. Sallusto F, Lenig D, Forster R, Lipp M, Lanzavecchia A. Two subsets of memory T lymphocytes with distinct homing potentials and effector functions. Nature. 1999;401(6754):708-12.

50. Macallan DC, Wallace D, Zhang Y, De Lara C, Worth AT, Ghattas H, Griffin GE, Beverley PC, Tough DF. Rapid turnover of effector-memory CD4(+) T cells in healthy humans. J Exp Med. 2004;200(2):255-60.

51. Riou C, Yassine-Diab B, Van Grevenynghe J, Somogyi R, Greller LD, Gagnon D, Gimmig S, Wilkinson P, Shi Y, Cameron MJ, Campos-Gonzalez R, Balderas RS, Kelvin D, Sekaly RP, Haddad EK. Convergence of TCR and cytokine signaling leads to FOXO3a phosphorylation and drives the survival of CD4+ central memory T cells. J Exp Med. 2007;204(1):79-91.

52. Gattinoni L, Lugli E, Ji Y, Pos Z, Paulos CM, Quigley MF, Almeida JR, Gostick E, Yu Z, Carpenito C, Wang E, Douek DC, Price DA, June CH, Marincola FM, Roederer M, Restifo NP. A human memory T cell subset with stem cell-like properties. Nat Med. 2011;17(10):1290-7.

53. Tabler CO, Lucera MB, Haqqani AA, McDonald DJ, Migueles SA, Connors M, Tilton JC. CD4+ memory stem cells are infected by HIV-1 in a manner regulated in part by SAMHD1 expression. JVirol. 2014;88(9):4976-86.

54. Buzon MJ, Sun H, Li C, Shaw A, Seiss K, Ouyang Z, Martin-Gayo E, Leng J, Henrich TJ, Li JZ, Pereyra F, Zurakowski R, Walker BD, Rosenberg ES, Yu XG, Lichterfeld M. HIV-1 persistence in CD4+T cells with stem cell-like properties. Nat Med. 2014;20(2):139-42.

55. Ostrowski MA, Chun TW, Justement SJ, Motola I, Spinelli MA, Adelsberger J, Ehler LA, Mizell SB, Hallahan CW, Fauci AS. Both memory and CD45RA+/CD62L+ naive CD4(+) T cells are infected in human immunodeficiency virus type 1-infected individuals. J Virol. 1999;73(8):6430-5.

56. Sun H, Kim D, Li X, Kiselinova M, Ouyang Z, Vandekerckhove L, Shang H, Rosenberg ES, Yu XG, Lichterfeld M. Th1/17 polarization of CD4 T cells supports HIV-1 persistence during antiretroviral therapy. J Virol. 2015;89(22):11284-93.

57. Perreau M, Savoye AL, De Crignis E, Corpataux JM, Cubas R, Haddad EK, De Leval L, Graziosi C, Pantaleo G. Follicular helper T cells serve as the major CD4 T cell compartment for HIV-1 infection, replication, and production. J Exp Med. 2013;210(1):143-56.

58. Folks TM, Kessler SW, Orenstein JM, Justement JS, Jaffe ES, Fauci AS. Infection and replication of HIV-1 in purified progenitor cells of normal human bone marrow. Science. 1988;242(4880):919-22.

59. Carter CC, Onafuwa-Nuga A, McNamara LA, Riddell JT, Bixby D, Savona MR, Collins KL. HIV-1 infects multipotent progenitor cells causing cell death and establishing latent cellular reservoirs. Nat Med. 2010;16(4):446-51.

60. McNamara LA, Onafuwa-Nuga A, Sebastian NT, Riddell JT, Bixby D, Collins KL. CD133+ hematopoietic progenitor cells harbor HIV genomes in a subset of optimally treated people with long-term viral suppression. J Infect Dis. 2013;207(12):1807-16.

61. Sebastian NT, Zaikos TD, Terry V, Taschuk F, McNamara LA, OnafuwaNuga A, Yucha R, Signer RAJ, Riddell JI, Bixby D, Markowitz N, Morrison $\mathrm{SJ}$, Collins KL. CD4 is expressed on a heterogeneous subset of hematopoietic progenitors, which persistently harbor CXCR4 and CCR5-tropic HIV proviral genomes in vivo. PLoS Pathog. 2017;13(7):e1006509.

62. Josefsson L, Eriksson S, Sinclair E, Ho T, Killian M, Epling L, Shao W, Lewis B, Bacchetti P, Loeb L, Custer J, Poole L, Hecht FM, Palmer S. Hematopoietic precursor cells isolated from patients on long-term suppressive HIV therapy did not contain HIV-1 DNA. J Infect Dis. 2012;206(1):28-34.

63. Durand CM, Ghiaur G, Siliciano JD, Rabi SA, Eisele EE, Salgado M, Shan L Lai JF, Zhang H, Margolick J, Jones RJ, Gallant JE, Ambinder RF, Siliciano RF. HIV-1 DNA is detected in bone marrow populations containing CD4+ T cells but is not found in purified CD34+ hematopoietic progenitor cells in most patients on antiretroviral therapy. J Infect Dis. 2012;205(6):1014-8. 
64. Williams KC, Corey S, Westmoreland SV, Pauley D, Knight H, deBakker C, Alvarez $X$, Lackner AA. Perivascular macrophages are the primary cell type productively infected by simian immunodeficiency virus in the brains of macaques: implications for the neuropathogenesis of AIDS. J Exp Med. 2001;193(8):905-15.

65. Cosenza MA, Zhao ML, Si Q, Lee SC. Human brain parenchymal microglia express CD14 and CD45 and are productively infected by HIV-1 in HIV-1 encephalitis. Brain Pathol. 2002;12(4):442-55.

66. He J, Chen Y, Farzan M, Choe H, Ohagen A, Gartner S, Busciglio J, Yang X, Hofmann W, Newman W, Mackay CR, Sodroski J, Gabuzda D. CCR3 and CCR5 are co-receptors for HIV-1 infection of microglia. Nature. 1997;385(6617):645-9.

67. Schnell G, Spudich S, Harrington P, Price RW, Swanstrom R. Compartmentalized human immunodeficiency virus type 1 originates from long-lived cells in some subjects with HIV-1-associated dementia. PLoS Pathog. 2009;5(4):e1000395.

68. Li GH, Henderson L, Nath A. Astrocytes as an HIV reservoir: mechanism of HIV infection. Curr HIV Res. 2016;14(5):373-81.

69. Canaud G, Dejucq-Rainsford N, Avettand-Fenoel V, Viard JP, Anglicheau D, Bienaime F, Muorah M, Galmiche L, Gribouval O, Noel LH, Satie AP, Martinez F, Sberro-Soussan R, Scemla A, Gubler MC, Friedlander G, Antignac C, Timsit MO, Onetti Muda A, Terzi F, Rouzioux C, Legendre C. The kidney as a reservoir for HIV-1 after renal transplantation. J Am Soc Nephrol. 2014;25(2):407-19.

70. Pinzone MR, O'Doherty U. Measuring integrated HIV DNA ex vivo and in vitro provides insights about how reservoirs are formed and maintained. Retrovirology. 2018;15(1):22.

71. Murray JM, McBride K, Boesecke C, Bailey M, Amin J, Suzuki K, Baker D, Zaunders JJ, Emery S, Cooper DA, Koelsch KK, Kelleher AD, Pint Study T. Integrated HIV DNA accumulates prior to treatment while episomal HIV DNA records ongoing transmission afterwards. AIDS. 2012;26(5):543-50.

72. Pinzone MR, Graf E, Lynch L, McLaughlin B, Hecht FM, Connors M, Migueles SA, Hwang WT, Nunnari G, O'Doherty U. Monitoring integration over time supports a role for cytotoxic T lymphocytes and ongoing replication as determinants of reservoir size. J Virol. 2016;90(23):10436-45.

73. Ananworanich J, Chomont N, Eller LA, Kroon E, Tovanabutra S, Bose M, Nau M, Fletcher JLK, Tipsuk S, Vandergeeten C, O'Connell RJ, Pinyakorn S, Michael N, Phanuphak N, Robb ML, Rv, groups RSs. HIV DNA set point is rapidly established in acute HIV infection and dramatically reduced by early ART. EBioMedicine. 2016;11:68-72.

74. Radebe M, Gounder K, Mokgoro M, Ndhlovu ZM, Mncube Z, Mkhize $L$, van der Stok M, Jaggernath M, Walker BD, Ndung'u T. Broad and persistent Gag-specific CD8+ T-cell responses are associated with viral control but rarely drive viral escape during primary HIV-1 infection. AIDS. 2015;29(1):23-33.

75. Trautmann L, Mbitikon-Kobo FM, Goulet JP, Peretz Y, Shi Y, Van Grevenynghe J, Procopio FA, Boulassel MR, Routy JP, Chomont N, Haddad EK, Sekaly RP. Profound metabolic, functional, and cytolytic differences characterize HIV-specific CD8 T cells in primary and chronic HIV infection. Blood. 2012;120(17):3466-77.

76. Anderson EM, Hill S, Bell J, Simonetti FR, Rehm C, Jones S, Gorelick R, Coffin J, Maldarelli F. Accumulation and persistence of deleted HIV proviruses following prolonged ART. In: International AIDS society conference on HIV science; Paris, France; 2017.

77. Boritz EA, Darko S, Swaszek L, Wolf G, Wells D, Wu X, Henry AR, Laboune F, Hu J, Ambrozak D, Hughes MS, Hoh R, Casazza JP, Vostal A, Bunis D, Nganou-Makamdop K, Lee JS, Migueles SA, Koup RA, Connors M, Moir S, Schacker T, Maldarelli F, Hughes SH, Deeks SG, Douek DC. Multiple origins of virus persistence during natural control of HIV infection. Cell. 2016;166(4):1004-15.

78. Maldarelli F, Wu X, Su L, Simonetti FR, Shao W, Hill S, Spindler J, Ferris AL, Mellors JW, Kearney MF, Coffin JM, Hughes SH. HIV latency. Specific HIV integration sites are linked to clonal expansion and persistence of infected cells. Science. 2014;345(6193):179-83.

79. Simonetti FR, Sobolewski MD, Fyne E, Shao W, Spindler J, Hattori J, Anderson EM, Watters SA, Hill S, Wu X, Wells D, Su L, Luke BT, Halvas EK, Besson G, Penrose KJ, Yang Z, Kwan RW, Van Waes C, Uldrick T, Citrin DE, Kovacs J, Polis MA, Rehm CA, Gorelick R, Piatak M, Keele BF, Kearney MF, Coffin JM, Hughes SH, Mellors JW, Maldarelli F. Clonally expanded
CD4+ T cells can produce infectious HIV-1 in vivo. Proc Natl Acad Sci USA. 2016;113(7):1883-8.

80. Wagner TA, McLaughlin S, Garg K, Cheung CY, Larsen BB, Styrchak S, Huang HC, Edlefsen PT, Mullins JI, Frenkel LM. HIV latency. Proliferation of cells with HIV integrated into cancer genes contributes to persistent infection. Science. 2014;345(6196):570-3.

81. Llano A, Barretina J, Gutierrez A, Blanco J, Cabrera C, Clotet B, Este JA. Interleukin-7 in plasma correlates with CD4 T-cell depletion and may be associated with emergence of syncytium-inducing variants in human immunodeficiency virus type 1-positive individuals. J Virol. 2001;75(21):10319-25.

82. Napolitano LA, Grant RM, Deeks SG, Schmidt D, De Rosa SC, Herzenberg LA, Herndier BG, Andersson J, McCune JM. Increased production of IL-7 accompanies HIV-1-mediated T-cell depletion: implications for T-cell homeostasis. Nat Med. 2001;7(1):73-9.

83. Fry TJ, Connick E, Falloon J, Lederman MM, Liewehr DJ, Spritzler J, Steinberg SM, Wood LV, Yarchoan R, Zuckerman J, Landay A, Mackall CL. A potential role for interleukin-7 in T-cell homeostasis. Blood. 2001;97(10):2983-90.

84. Srinivasula S, Lempicki RA, Adelsberger JW, Huang CY, Roark J, Lee PI, Rupert A, Stevens R, Sereti I, Lane HC, Di Mascio M, Kovacs JA. Differential effects of HIV viral load and CD4 count on proliferation of naive and memory CD4 and CD8 T lymphocytes. Blood. 2011;118(2):262-70.

85. Catalfamo M, Wilhelm C, Tcheung L, Proschan M, Friesen T, Park JH, Adelsberger J, Baseler M, Maldarelli F, Davey R, Roby G, Rehm C, Lane C. CD4 and CD8 T cell immune activation during chronic HIV infection: roles of homeostasis, HIV, type I IFN, and IL-7. J Immunol. 2011;186(4):2106-16.

86. Sereti I, Dunham RM, Spritzler J, Aga E, Proschan MA, Medvik K, Battaglia CA, Landay AL, Pahwa S, Fischl MA, Asmuth DM, Tenorio AR, Altman JD, Fox L, Moir S, Malaspina A, Morre M, Buffet R, Silvestri G, Lederman MM, Team AS. IL-7 administration drives T cell-cycle entry and expansion in HIV-1 infection. Blood. 2009:113(25):6304-14.

87. Levy Y, Lacabaratz C, Weiss L, Viard JP, Goujard C, Lelievre JD, Boue F, Molina JM, Rouzioux C, Avettand-Fenoel V, Croughs T, Beq S, Thiebaut R, Chene G, Morre M, Delfraissy JF. Enhanced T cell recovery in HIV-1-infected adults through IL-7 treatment. J Clin Invest. 2009;1 19(4):997-1007.

88. Vandergeeten C, Fromentin R, DaFonseca S, Lawani MB, Sereti I, Lederman MM, Ramgopal M, Routy JP, Sekaly RP, Chomont N. Interleukin-7 promotes HIV persistence during antiretroviral therapy. Blood. 2013;121(21):4321-9.

89. Bosque A, Famiglietti M, Weyrich AS, Goulston C, Planelles V. Homeostatic proliferation fails to efficiently reactivate HIV-1 latently infected central memory CD4+T cells. PLoS Pathog. 2011;7(10):e1002288.

90. Boyman O, Sprent J. The role of interleukin-2 during homeostasis and activation of the immune system. Nat Rev Immunol. 2012;12(3):180-90.

91. Douek DC, Brenchley JM, Betts MR, Ambrozak DR, Hill BJ, Okamoto Y, Casazza JP, Kuruppu J, Kunstman K, Wolinsky S, Grossman Z, Dybul M, Oxenius A, Price DA, Connors M, Koup RA. HIV preferentially infects HIVspecific CD4+ T cells. Nature. 2002;417(6884):95-8.

92. Doitsh G, Cavrois M, Lassen KG, Zepeda O, Yang Z, Santiago ML, Hebbeler AM, Greene WC. Abortive HIV infection mediates CD4 T cell depletion and inflammation in human lymphoid tissue. Cell. 2010;143(5):789-801.

93. Doitsh G, Galloway NL, Geng X, Yang Z, Monroe KM, Zepeda O, Hunt PW, Hatano H, Sowinski S, Munoz-Arias I, Greene WC. Cell death by pyroptosis drives CD4 T-cell depletion in HIV-1 infection. Nature. 2014:505(7484):509-14.

94. Hill AL. Mathematical Models of HIV Latency. Curr. Topics Microbiol. Immunol. 2018:417:131-56.

95. Wang S, Hottz P, Schechter M, Rong L. Modeling the slow CD4+ $T$ cell decline in HIV-infected individuals. PLoS Comput Biol. 2015;11(12):e1004665.

96. Klatt NR, Chomont N, Douek DC, Deeks SG. Immune activation and HIV persistence: implications for curative approaches to HIV infection. Immunol Rev. 2013;254(1):326-42.

97. Mazzuca P, Caruso A, Caccuri F. HIV-1 infection, microenvironment and endothelial cell dysfunction. New Microbiol. 2016;39(3):163-73. 
98. Wang Z, Simonetti FR, Siliciano RF, Laird GM. Measuring replication competent HIV-1: advances and challenges in defining the latent reservoir. Retrovirology. 2018;15(1):21.

99. Rouzioux C, Melard A, Avettand-Fenoel V. Quantification of total HIV1-DNA in peripheral blood mononuclear cells. Methods Mol Biol. 2014;1087:261-70.

100. Chun TW, Murray D, Justement JS, Hallahan CW, Moir S, Kovacs C, Fauci AS. Relationship between residual plasma viremia and the size of HIV proviral DNA reservoirs in infected individuals receiving effective antiretroviral therapy. J Infect Dis. 2011;204(1):135-8.

101. Soriano-Sarabia N, Bateson RE, Dahl NP, Crooks AM, Kuruc JD, Margolis DM, Archin NM. Quantitation of replication-competent HIV-1 in populations of resting CD4+ T cells. J Virol. 2014;88(24):14070-7.

102. Chun TW, Nickle DC, Justement JS, Meyers JH, Roby G, Hallahan CW, Kottilil S, Moir S, Mican JM, Mullins JI, Ward DJ, Kovacs JA, Mannon PJ, Fauci AS. Persistence of HIV in gut-associated lymphoid tissue despite long-term antiretroviral therapy. J Infect Dis. 2008;197(5):714-20.

103. Hatano H, Somsouk M, Sinclair E, Harvill K, Gilman L, Cohen M, Hoh R, Hunt PW, Martin JN, Wong JK, Deeks SG, YukI SA. Comparison of HIV DNA and RNA in gut-associated lymphoid tissue of HIV-infected controllers and noncontrollers. AIDS. 2013;27(14):2255-60.

104. Rutsaert S, Bosman K, Trypsteen W, Nijhuis M, Vandekerckhove L. Digital PCR as a tool to measure HIV persistence. Retrovirology. 2018;15(1):16.

105. Busby E, Whale AS, Ferns RB, Grant PR, Morley G, Campbell J, Foy CA, Nastouli E, Huggett JF, Garson JA. Instability of 8 E5 calibration standard revealed by digital PCR risks inaccurate quantification of HIV DNA in clinical samples by qPCR. Sci Rep. 2017;7(1):1209.

106. Strain MC, Lada SM, Luong T, Rought SE, Gianella S, Terry VH, Spina CA, Woelk CH, Richman DD. Highly precise measurement of HIV DNA by droplet digital PCR. PLOS ONE. 2013;8(4):e55943.

107. Henrich TJ, Gallien S, Li JZ, Pereyra F, Kuritzkes DR. Low-level detection and quantitation of cellular HIV-1 DNA and 2-LTR circles using droplet digital PCR. J Virol Methods. 2012;186(1-2):68-72.

108. Kiselinova M, Pasternak AO, De Spiegelaere W, Vogelaers D, Berkhout B, Vandekerckhove L. Comparison of droplet digital PCR and seminested real-time PCR for quantification of cell-associated HIV-1 RNA. PLoS ONE. 2014;9(1):e85999

109. Dunay GA, Solomatina A, Kummer S, Hufner A, Bialek JK, Eberhard JM, Tolosa E, Hauber J, Schulze Zur Wiesch J. Assessment of the HIV-1 reservoir in CD4+ regulatory T cells by a droplet digital PCR based approach. Virus Res. 2017;240:107-11.

110. de Oliveira MF, Gianella S, Letendre S, Scheffler K, Kosakovsky Pond SL, Smith DM, Strain M, Ellis RJ. Comparative analysis of cell-associated HIV DNA levels in cerebrospinal fluid and peripheral blood by droplet digital PCR. PLOS ONE. 2015;10(10):e0139510.

111. Bruner KM, Murray AJ, Pollack RA, Soliman MG, Laskey SB, Capoferri AA, Lai J, Strain MC, Lada SM, Hoh R, Ho YC, Richman DD, Deeks SG, Siliciano JD, Siliciano RF. Defective proviruses rapidly accumulate during acute HIV-1 infection. Nat Med. 2016;22(9):1043-9.

112. Avettand-Fenoel V, Hocqueloux L, Ghosn J, Cheret A, Frange P, Melard A, Viard JP, Rouzioux C. Total HIV-1 DNA, a marker of viral reservoir dynamics with clinical implications. Clin Microbiol Rev. 2016;29(4):859-80.

113. Williams JP, Hurst J, Stohr W, Robinson N, Brown H, Fisher M, Kinloch S, Cooper D, Schechter M, Tambussi G, Fidler S, Carrington M, Babiker A, Weber J, Koelsch KK, Kelleher AD, Phillips RE, Frater J, Investigators SP. HIV-1 DNA predicts disease progression and post-treatment virological control. Elife. 2014;3:e03821.

114. Kiselinova M, De Spiegelaere W, Buzon MJ, Malatinkova E, Lichterfeld M, Vandekerckhove L. Integrated and total HIV-1 DNA predict ex vivo viral outgrowth. PLoS Pathog. 2016;12(3):e1005472.

115. Bruner KM, Pollack RA, Murray AJ, Soliman MG, Laskey SB, Strain M, Richman D, Deeks S, Siliciano J, Siliciano R. Rapid accumulation of defective proviruses complicates HIV-1 reservoir measurements. In: 25th conference on retroviruses and opportunistic infections, Boston, MA; 2018

116. Gratzner HG. Monoclonal antibody to 5-bromo- and 5-iododeoxyuridine: a new reagent for detection of DNA replication. Science. 1982;218(4571):474-5.

117. Kovacs JA, Lempicki RA, Sidorov IA, Adelsberger JW, Herpin B, Metcalf JA, Sereti I, Polis MA, Davey RT, Tavel J, Falloon J, Stevens R, Lambert L, Dewar R, Schwartzentruber DJ, Anver MR, Baseler MW, Masur H, Dimitrov DS, Lane HC. Identification of dynamically distinct subpopulations of T lymphocytes that are differentially affected by HIV. J Exp Med. 2001;194(12):1731-41.

118. Hellerstein MK, Hoh RA, Hanley MB, Cesar D, Lee D, Neese RA, McCune $J$ M. Subpopulations of long-lived and short-lived T cells in advanced HIV-1 infection. J Clin Invest. 2003;112(6):956-66.

119. Golumbeanu M, Cristinelli S, Rato S, Munoz M, Cavassini M, Beerenwinkel N, Ciuffi A. Single-cell RNA-Seq reveals transcriptional heterogeneity in latent and reactivated HIV-infected cells. Cell Rep. 2018;23(4):942-50.

120. Ciuffi A, Rato S, Telenti A. Single-cell genomics for virology. Viruses 2016;8(5):pii:e123.

121. Kok YL, Ciuffi A, Metzner KJ. Unravelling HIV-1 latency, one cell at a time. Trends Microbiol. 2017;25(11):932-41.

122. Phetsouphanh C, Zaunders JJ, Kelleher AD. Detecting antigen-specific T cell responses: from bulk populations to single cells. Int J Mol Sci. 2015;16(8):18878-93.

123. Molony RD, Malawista A, Montgomery RR. Reduced dynamic range of antiviral innate immune responses in aging. Exp Gerontol. 2017:107:130-35.

124. Nikolich-Zugich J. The twilight of immunity: emerging concepts in aging of the immune system. Nat Immunol. 2018;19(1):10-9.

125. Pallikkuth S, de Armas L, Rinaldi S, Pahwa S. T follicular helper cells and B cell dysfunction in aging and HIV-1 infection. Front Immunol. 2017;8:1380.

126. Hu WS, Hughes SH. HIV-1 reverse transcription. Cold Spring Harb Perspect Med. 2012;2(10):pii:a006882.

127. Dyda F, Hickman AB, Jenkins TM, Engelman A, Craigie R, Davies DR. Crystal structure of the catalytic domain of HIV-1 integrase: similarity to other polynucleotidyl transferases. Science. 1994;266(5193):1981-6.

128. Jenkins TM, Hickman AB, Dyda F, Ghirlando R, Davies DR, Craigie R. Catalytic domain of human immunodeficiency virus type 1 integrase: identification of a soluble mutant by systematic replacement of hydrophobic residues. Proc Natl Acad Sci USA. 1995;92(13):6057-61.

129. Miller MD, Bor YC, Bushman F. Target DNA capture by HIV-1 integration complexes. Curr Biol. 1995;5(9):1047-56.

130. Hare S, Gupta SS, Valkov E, Engelman A, Cherepanov P. Retroviral intasome assembly and inhibition of DNA strand transfer. Nature. 2010;464(7286):232-6.

131. Valkov E, Gupta SS, Hare S, Helander A, Roversi P, McClure M, Cherepanov P. Functional and structural characterization of the integrase from the prototype foamy virus. Nucleic Acids Res. 2009;37(1):243-55.

132. Hare S, Di Nunzio F, Labeja A, Wang J, Engelman A, Cherepanov P. Structural basis for functional tetramerization of lentiviral integrase. PLoS Pathog. 2009;5(7):e1000515.

133. Li X, Krishnan L, Cherepanov P, Engelman A. Structural biology of retroviral DNA integration. Virology. 2011;411(2):194-205.

134. Cherepanov P, Maertens GN, Hare S. Structural insights into the retroviral DNA integration apparatus. Curr Opin Struct Biol. 2011;21(2):249-56.

135. Engelman AN, Cherepanov P. Retroviral intasomes arising. Curr Opin Struct Biol. 2017:47:23-9.

136. Feng L, Larue RC, Slaughter A, KessI J, Kvaratskhelia M. HIV-1 integrase multimerization as a therapeutic target. Curr Top Microbiol Immunol. 2015:389:93-119.

137. Jurado KA, Wang H, Slaughter A, Feng L, KessI JJ, Koh Y, Wang W, Ballandras-Colas A, Patel PA, Fuchs JR, Kvaratskhelia M, Engelman A. Allosteric integrase inhibitor potency is determined through the inhibition of HIV-1 particle maturation. Proc Natl Acad Sci USA. 2013;1 10(21):8690-5.

138. Balakrishnan M, Yant SR, Tsai L, O'Sullivan C, Bam RA, Tsai A, NiedzielaMajka A, Stray KM, Sakowicz R, Cihlar T. Non-catalytic site HIV-1 integrase inhibitors disrupt core maturation and induce a reverse transcription block in target cells. PLoS ONE. 2013;8(9):e74163.

139. Fontana J, Jurado KA, Cheng N, Ly NL, Fuchs JR, Gorelick RJ, Engelman AN, Steven AC. Distribution and redistribution of HIV-1 nucleocapsid protein in immature, mature, and integrase-inhibited virions: a role for integrase in maturation. J Virol. 2015;89(19):9765-80.

140. Madison MK, Lawson DQ, Elliott J, Ozanturk AN, Koneru PC, Townsend D, Errando M, Kvaratskhelia M, Kutluay SB. Allosteric HIV-1 integrase inhibitors lead to premature degradation of the viral RNA genome and integrase in target cells. J Virol. 2017;91(17):pii:e00821-17.

141. Ballandras-Colas A, Maskell DP, Serrao E, Locke J, Swuec P, Jonsson SR, Kotecha A, Cook NJ, Pye VE, Taylor IA, Andresdottir V, Engelman AN, 
Costa A, Cherepanov P. A supramolecular assembly mediates lentiviral DNA integration. Science. 2017;355(6320):93-5.

142. Lesbats P, Engelman AN, Cherepanov P. Retroviral DNA Integration. Chem Rev. 2016;116(20):12730-57.

143. Ciuffi A, Bushman FD. Retroviral DNA integration: HIV and the role of LEDGF/p75. Trends Genet. 2006;22(7):388-95.

144. Craigie R, Bushman FD. Host factors in retroviral integration and the selection of integration target Sites. Microbiol Spectr. 2014. https://doi. org/10.1128/microbiolspec.MDNA3-0026-2014.

145. Debyser Z, Christ F, De Rijck J, Gijsbers R. Host factors for retroviral integration site selection. Trends Biochem Sci. 2015;40(2):108-16.

146. Demeulemeester J, De Rijck J, Gijsbers R, Debyser Z. Retroviral integration: site matters: mechanisms and consequences of retroviral integration site selection. BioEssays. 2015;37(11):1202-14.

147. Engelman A. The roles of cellular factors in retroviral integration. Curr Top Microbiol Immunol. 2003;281:209-38.

148. Suzuki Y, Craigie R. The road to chromatin-nuclear entry of retroviruses. Nat Rev Microbiol. 2007:5(3):187-96.

149. Tsirkone VG, Blokken J, De Wit F, Breemans J, De Houwer S, Debyser Z, Christ F, Strelkov SV. N-terminal half of transportin SR2 interacts with HIV integrase. J Biol Chem. 2017;292(23):9699-710.

150. Burdick RC, Hu WS, Pathak VK. Nuclear import of APOBEC3Flabeled HIV-1 preintegration complexes. Proc Natl Acad Sci USA. 2013;110(49):E4780-9.

151. Luo X, Yang W, Gao G. SUN1 regulates HIV-1 nuclear import in a manner dependent on the interaction between the viral capsid and cellular cyclophilin A. J Virol. 2018:92(13):pi:e00229-18.

152. Blokken J, De Rijck J, Christ F, Debyser Z. Protein-protein and proteinchromatin interactions of LEDGF/p75 as novel drug targets. Drug Discov Today Technol. 2017;24:25-31.

153. Demeulemeester J, Blokken J, De Houwer S, Dirix L, Klaassen H, Marchand A, Chaltin P, Christ F, Debyser Z. Inhibitors of the integrasetransportin-SR2 interaction block HIV nuclear import. Retrovirology. 2018;15(1):5.

154. Desimmie BA, Schrijvers R, Demeulemeester J, Borrenberghs D, Weydert C, Thys W, Vets S, Van Remoortel B, Hofkens J, De Rijck J, Hendrix J, Bannert N, Gijsbers R, Christ F, Debyser Z. LEDGINs inhibit late stage HIV-1 replication by modulating integrase multimerization in the virions. Retrovirology. 2013;10:57

155. Francis AC, Melikyan GB. Single HIV-1 imaging reveals progression of infection through CA-dependent steps of docking at the nuclear pore, uncoating, and nuclear transport. Cell Host Microbe. 2018;23(4):536-48 e6.

156. Schroder AR, Shinn P, Chen H, Berry C, Ecker JR, Bushman F. HIV-1 integration in the human genome favors active genes and local hotspots. Cell. 2002;110(4):521-9.

157. Kvaratskhelia M, Sharma A, Larue RC, Serrao E, Engelman A. Molecular mechanisms of retroviral integration site selection. Nucleic Acids Res. 2014:42(16):10209-25.

158. Ciuffi A. The benefits of integration. Clin Microbiol Infect. 2016:22(4):324-32.

159. Ciuffi A, Llano M, Poeschla E, Hoffmann C, Leipzig J, Shinn P, Ecker JR, Bushman F. A role for LEDGF/p75 in targeting HIV DNA integration. Nat Med. 2005;11(12):1287-9.

160. Cherepanov P, Ambrosio AL, Rahman S, Ellenberger T, Engelman A. Structural basis for the recognition between HIV-1 integrase and transcriptional coactivator p75. Proc Natl Acad Sci USA. 2005;102(48):17308-13.

161. Turlure F, Maertens G, Rahman S, Cherepanov P, Engelman A. A tripartite DNA-binding element, comprised of the nuclear localization signal and two AT-hook motifs, mediates the association of LEDGF/p75 with chromatin in vivo. Nucleic Acids Res. 2006:34(5):1653-65.

162. Ferris AL, Wu X, Hughes CM, Stewart C, Smith SJ, Milne TA, Wang GG, Shun MC, Allis CD, Engelman A, Hughes SH. Lens epithelium-derived growth factor fusion proteins redirect HIV-1 DNA integration. Proc Natl Acad Sci USA. 2010:107(7):3135-40.

163. Krull S, Dorries J, Boysen B, Reidenbach S, Magnius L, Norder H, Thyberg $\mathrm{J}$, Cordes VC. Protein Tpr is required for establishing nuclear pore-associated zones of heterochromatin exclusion. EMBO J. 2010;29(10):1659-73.

164. Lelek M, Casartelli N, Pellin D, Rizzi E, Souque P, Severgnini M, Di Serio C, Fricke T, Diaz-Griffero F, Zimmer C, Charneau P. Di Nunzio F. Chromatin organization at the nuclear pore favours HIV replication. Nat Commun. 2015;6:6483.

165. Marini B, Kertesz-Farkas A, Ali H, Lucic B, Lisek K, Manganaro L, Pongor S, Luzzati R, Recchia A, Mavilio F, Giacca M, Lusic M. Nuclear architecture dictates HIV-1 integration site selection. Nature. 2015;521(7551):227-31.

166. Stultz RD, Cenker JJ, McDonald D. Imaging HIV-1 genomic DNA from entry through productive infection. J Virol. 2017;91(9):pii:e00034-17.

167. Di Primio C, Quercioli V, Allouch A, Gijsbers R, Christ F, Debyser Z, Arosio D. Cereseto A. Single-cell imaging of HIV-1 provirus (SCIP). Proc Natl Acad Sci USA. 2013;110(14):5636-41.

168. Ma Y, Wang M, Li W, Zhang Z, Zhang X, Tan T, Zhang XE, Cui Z. Live cell imaging of single genomic loci with quantum dot-labeled TALEs. Nat Commun. 2017:8:15318.

169. Sardo L, Lin A, Khakhina S, Beckman L, Ricon L, Elbezanti W, Jaison T, Vishwasrao H, Shroff H, Janetopoulos C, Klase ZA. Real-time visualization of chromatin modification in isolated nuclei. J Cell Sci. 2017;130(17):2926-40.

170. Burdick RC, Delviks-Frankenberry KA, Chen J, Janaka SK, Sastri J, Hu WS, Pathak VK. Dynamics and regulation of nuclear import and nuclear movements of HIV-1 complexes. PLoS Pathog. 2017:13(8):e1006570.

171. Wong RW, Mamede JI, Hope TJ. Impact of nucleoporin-mediated chromatin localization and nuclear architecture on HIV integration site selection. J Virol. 2015;89(19):9702-5.

172. Puray-Chavez M, Tedbury PR, Huber AD, Ukah OB, Yapo V, Liu D, Ji J, Wolf JJ, Engelman AN, Sarafianos SG. Multiplex single-cell visualization of nucleic acids and protein during HIV infection. Nat Commun. 2017:8(1):1882

173. Farnet $\mathrm{CM}$, Haseltine WA. Circularization of human immunodeficiency virus type 1 DNA in vitro. JVirol. 1991;65(12):6942-52.

174. Pauza CD, Trivedi P, McKechnie TS, Richman DD, Graziano FM. 2-LTR circular viral DNA as a marker for human immunodeficiency virus type 1 infection in vivo. Virology. 1994;205(2):470-8.

175. Sharkey ME, Teo I, Greenough T, Sharova N, Luzuriaga K, Sullivan JL, Bucy RP, Kostrikis LG, Haase A, Veryard C, Davaro RE, Cheeseman SH, Daly JS, Bova C, Ellison RT 3rd, Mady B, Lai KK, Moyle G, Nelson M, Gazzard B, Shaunak S, Stevenson M. Persistence of episomal HIV-1 infection intermediates in patients on highly active anti-retroviral therapy. Nat Med. 2000;6(1):76-81.

176. Pierson TC, Kieffer TL, Ruff CT, Buck C, Gange SJ, Siliciano RF. Intrinsic stability of episomal circles formed during human immunodeficiency virus type 1 replication. J Virol. 2002;76(8):4138-44.

177. Koelsch KK, Liu L, Haubrich R, May S, Havlir D, Gunthard HF, Ignacio CC, Campos-Soto P, Little SJ, Shafer R, Robbins GK, D'Aquila RT, Kawano Y, Young K, Dao P, Spina CA, Richman DD, Wong JK. Dynamics of total, linear nonintegrated, and integrated HIV-1 DNA in vivo and in vitro. J Infect Dis. 2008;197(3):411-9.

178. Pace MJ, Graf EH, O'Doherty U. HIV 2-long terminal repeat circular DNA is stable in primary CD4+ T Cells. Virology. 2013;441(1):18-21.

179. Drylewicz J, Vrisekoop N, Mugwagwa T, de Boer AB, Otto SA, Hazenberg MD, Tesselaar K, de Boer RJ, Borghans JA. Reconciling longitudinal naive T-cell and TREC dynamics during HIV-1 infection. PLOS ONE. 2016;11(3):e0152513.

180. Mack KD, Jin X, Yu S, Wei R, Kapp L, Green C, Herndier B, Abbey NW Elbaggari A, Liu Y, McGrath MS. HIV insertions within and proximal to host cell genes are a common finding in tissues containing high levels of HIV DNA and macrophage-associated p24 antigen expression. J Acquir Immune Defic Syndr. 2003;33(3):308-20.

181. Ikeda T, Shibata J, Yoshimura K, Koito A, Matsushita S. Recurrent $\mathrm{HIV}$-1 integration at the BACH2 locus in resting CD4+T cell populations during effective highly active antiretroviral therapy. J Infect Dis. 2007;195(5):716-25

182. Han Y, Lassen K, Monie D, Sedaghat AR, Shimoji S, Liu X, Pierson TC, Margolick JB, Siliciano RF, Siliciano JD. Resting CD4+T cells from human immunodeficiency virus type 1 (HIV-1)-infected individuals carry integrated HIV-1 genomes within actively transcribed host genes. J Virol. 2004:78(12):6122-33.

183. Sasaki S, Ito E, Toki T, Maekawa T, Kanezaki R, Umenai T, Muto A, Nagai H, Kinoshita T, Yamamoto M, Inazawa J, Taketo MM, Nakahata T, Igarashi K, Yokoyama M. Cloning and expression of human B cell-specific transcription factor BACH2 mapped to chromosome 6q15. Oncogene. 2000;19(33):3739-49. 
184. Meekings KN, Leipzig J, Bushman FD, Taylor GP, Bangham CR. HTLV-1 integration into transcriptionally active genomic regions is associated with proviral expression and with HAM/TSP. PLoS Pathog. 2008;4(3):e1000027

185. Gillet NA, Malani N, Melamed A, Gormley N, Carter R, Bentley D, Berry C, Bushman FD, Taylor GP, Bangham CR. The host genomic environment of the provirus determines the abundance of HTLV-1-infected T-cell clones. Blood. 2011;117(11):3113-22.

186. Berry CC, Gillet NA, Melamed A, Gormley N, Bangham CR, Bushman FD. Estimating abundances of retroviral insertion sites from DNA fragment length data. Bioinformatics. 2012;28(6):755-62.

187. Melamed A, Witkover AD, Laydon DJ, Brown R, Ladell K, Miners K, Rowan AG, Gormley N, Price DA, Taylor GP, Murphy EL, Bangham CR. Clonality of HTLV-2 in natural infection. PLoS Pathog. 2014;10(3):e1004006.

188. De Ravin SS, Su L, Theobald N, Choi U, Macpherson JL, Poidinger M, Symonds G, Pond SM, Ferris AL, Hughes SH, Malech HL, Wu X. Enhancers are major targets for murine leukemia virus vector integration. J Virol. 2014;88(8):4504-13.

189. Muehlich S, Hampl V, Khalid S, Singer S, Frank N, Breuhahn K, Gudermann T, Prywes R. The transcriptional coactivators megakaryoblastic leukemia 1/2 mediate the effects of loss of the tumor suppressor deleted in liver cancer 1. Oncogene. 2012;31(35):3913-23.

190. Selvaraj A, Prywes R. Megakaryoblastic leukemia-1/2, a transcriptional co-activator of serum response factor, is required for skeletal myogenic differentiation. J Biol Chem. 2003;278(43):41977-87.

191. Huang D, Sumegi J, Dal Cin P, Reith JD, Yasuda T, Nelson M, Muirhead $D$, Bridge JA. C11 orf95-MKL2 is the resulting fusion oncogene of $\mathrm{t}(11 ; 16)(\mathrm{q} 13 ; \mathrm{p} 13)$ in chondroid lipoma. Genes Chromosomes Cancer. 2010;49(9):810-8.

192. Siegfried A, Romary C, Escudie F, Nicaise Y, Grand D, Rochaix P, Barres B, Vergez S, Chevreau C, Coindre JM, Uro-Coste E, Le Guellec S. RREB1MKL2 fusion in biphenotypic "oropharyngeal" sarcoma: New entity or part of the spectrum of biphenotypic sinonasal sarcomas? Genes Chromosomes Cancer. 2017.

193. O'Sullivan NC, Pickering M, Di Giacomo D, Loscher JS, Murphy KJ. Mkl transcription cofactors regulate structural plasticity in hippocampal neurons. Cereb Cortex. 2010;20(8):1915-25.

194. Parmacek MS. Myocardin-related transcription factors: critical coactivators regulating cardiovascular development and adaptation. Circ Res. 2007; 100(5):633-44.

195. Cen B, Selvaraj A, Prywes R. Myocardin/MKL family of SRF coactivators: key regulators of immediate early and muscle specific gene expression. J Cell Biochem. 2004;93(1):74-82.

196. Igarashi K, Ochiai K, Itoh-Nakadai A, Muto A. Orchestration of plasma cell differentiation by Bach2 and its gene regulatory network. Immunol Rev. 2014;261(1):116-25.

197. Muto A, Hoshino H, Madisen L, Yanai N, Obinata M, Karasuyama H, Hayashi N, Nakauchi H, Yamamoto M, Groudine M, Igarashi K. Identification of Bach2 as a B-cell-specific partner for small maf proteins that negatively regulate the immunoglobulin heavy chain gene $3^{\prime}$ enhancer. EMBO J. 1998;17(19):5734-43.

198. Merup M, Moreno TC, Heyman M, Ronnberg K, Grander D Detlofsson R, Rasool O, Liu Y, Soderhall S, Juliusson G, Gahrton G, Einhorn S. 6q deletions in acute lymphoblastic leukemia and non-Hodgkin's lymphomas. Blood. 1998;91(9):3397-400

199. Swaminathan $\mathrm{S}$, Huang $\mathrm{C}$, Geng H, Chen Z, Harvey R, Kang H, Ng C, Titz B, Hurtz C, Sadiyah MF, Nowak D, Thoennissen GB, Rand V, Graeber TG, Koeffler HP, Carroll WL, Willman CL, Hall AG, Igarashi K, Melnick A, Muschen M. BACH2 mediates negative selection and p53-dependent tumor suppression at the pre-B cell receptor checkpoint. Nat Med. 2013:19(8):1014-22.

200. Kobayashi S, Taki T, Chinen Y, Tsutsumi Y, Ohshiro M, Kobayashi T, Matsumoto Y, Kuroda J, Horiike S, Nishida K, Taniwaki M. Identification of IGHCdelta-BACH2 fusion transcripts resulting from cryptic chromosomal rearrangements of 14q32 with $6 \mathrm{q} 15$ in aggressive B-cell lymphoma/leukemia. Genes Chromosomes Cancer. 2011;50(4):207-16.

201. Roychoudhuri R, Hirahara K, Mousavi K, Clever D, Klebanoff CA, Bonelli M, Sciume G, Zare H, Vahedi G, Dema B, Yu Z, Liu H, Takahashi H, Rao M, Muranski P, Crompton JG, Punkosdy G, Bedognetti D, Wang E, Hoffmann V, Rivera J, Marincola FM, Nakamura A, Sartorelli V, Kanno Y,
Gattinoni L, Muto A, Igarashi K, O'Shea JJ, Restifo NP. BACH2 represses effector programs to stabilize T(reg)-mediated immune homeostasis. Nature. 2013:498(7455):506-10.

202. Tsukumo S, Unno M, Muto A, Takeuchi A, Kometani K, Kurosaki T, Igarashi K, Saito T. Bach2 maintains T cells in a naive state by suppressing effector memory-related genes. Proc Natl Acad Sci USA. 2013;110(26):10735-40.

203. Hu G, Chen J. A genome-wide regulatory network identifies key transcription factors for memory CD8(+) T-cell development. Nat Commun. 2013;4:2830.

204. Richer MJ, Lang ML, Butler NS. T cell fates zipped up: how the Bach2 basic leucine zipper transcriptional repressor directs $T$ cell differentiation and function. J Immunol. 2016;197(4):1009-15.

205. Cesana D, Santoni de Sio FR, Rudilosso L, Gallina P, Calabria A, Beretta S, Merelli I, Bruzzesi E, Passerini L, Nozza S, Vicenzi E, Poli G, Gregori S, Tambussi G, Montini E. HIV-1-mediated insertional activation of STAT5B and $\mathrm{BACH} 2$ trigger viral reservoir in T regulatory cells. Nat Commun. 2017:8(1):498

206. Biggar RJ, Engels EA, Frisch M, Goedert JJ, Group ACMRS. Risk of T-cell lymphomas in persons with AIDS. J Acquir Immune Defic Syndr. 2001;26(4):371-6

207. Gilardin L, Copie-Bergman C, Galicier L, Meignin V, Briere J, Timsit JF, Bouchaud O, Gaulard P, Oksenhendler E, Gerard L. Peripheral T-cell lymphoma in HIV-infected patients: a study of 17 cases in the combination antiretroviral therapy era. Br J Haematol. 2013;161(6):843-51.

208. Cohn LB, Silva IT, Oliveira TY, Rosales RA, Parrish EH, Learn GH, Hahn $\mathrm{BH}$, Czartoski JL, McElrath MJ, Lehmann C, Klein F, Caskey M, Walker BD, Siliciano JD, Siliciano RF, Jankovic M, Nussenzweig MC. HIV-1 integration landscape during latent and active infection. Cell. 2015;160(3):420-32.

209. Bangham CRM, Human T. Cell leukemia virus type 1: persistence and pathogenesis. Annu Rev Immunol. 2018;36:43-71.

210. Shao W, Shan J, Kearney MF, Wu X, Maldarelli F, Mellors JW, Luke B, Coffin JM, Hughes SH. Retrovirus integration database (RID): a public database for retroviral insertion sites into host genomes. Retrovirology. 2016;13(1):47.

211. Kearney MF, Spindler J, Shao W, Yu S, Anderson EM, O'Shea A, Rehm C, Poethke C, Kovacs N, Mellors JW, Coffin JM, Maldarelli F. Lack of detectable HIV-1 molecular evolution during suppressive antiretroviral therapy. PLoS Pathog. 2014;10(3):e1004010.

212. Bailey JR, Sedaghat AR, Kieffer T, Brennan T, Lee PK, Wind-Rotolo M, Haggerty CM, Kamireddi AR, Liu Y, Lee J, Persaud D, Gallant JE, Cofrancesco J Jr, Quinn TC, Wilke CO, Ray SC, Siliciano JD, Nettles RE, Siliciano RF. Residual human immunodeficiency virus type 1 viremia in some patients on antiretroviral therapy is dominated by a small number of invariant clones rarely found in circulating CD4+ T cells. J Virol. 2006;80(13):6441-57.

213. Josefsson L, von Stockenstrom S, Faria NR, Sinclair E, Bacchetti P, Killian M, Epling L, Tan A, Ho T, Lemey P, Shao W, Hunt PW, Somsouk M, Wylie W, Douek DC, Loeb L, Custer J, Hoh R, Poole L, Deeks SG, Hecht F, Palmer S. The HIV-1 reservoir in eight patients on long-term suppressive antiretroviral therapy is stable with few genetic changes over time. Proc Natl Acad Sci USA. 2013;110(51):E4987-96.

214. Rong L, Perelson AS. Modeling latently infected cell activation: viral and latent reservoir persistence, and viral blips in HIV-infected patients on potent therapy. PLoS Comput Biol. 2009;5(10):e1000533.

215. Bradley LM, Haynes L, Swain SL. IL-7: maintaining T-cell memory and achieving homeostasis. Trends Immunol. 2005;26(3):172-6.

216. Chetoui N, Boisvert M, Gendron S, Aoudjit F. Interleukin-7 promotes the survival of human CD4+ effector/memory T cells by up-regulating $\mathrm{BCl}-2$ proteins and activating the JAK/STAT signalling pathway. Immunology. 2010;130(3):418-26.

217. Chomont N, El-Far M, Ancuta P, Trautmann L, Procopio FA, Yassine-Diab B, Boucher G, Boulassel MR, Ghattas G, Brenchley JM, Schacker TW, Hill BJ, Douek DC, Routy JP, Haddad EK, Sekaly RP. HIV reservoir size and persistence are driven by T cell survival and homeostatic proliferation. Nat Med. 2009;15(8):893-900.

218. Goh WC, Rogel ME, Kinsey CM, Michael SF, Fultz PN, Nowak MA, Hahn $\mathrm{BH}$, Emerman M. HIV-1 Vpr increases viral expression by manipulation of the cell cycle: a mechanism for selection of Vpr in vivo. Nat Med. 1998;4(1):65-71. 
219. Musick A, Spindler J, Keele BF, Bale MJ, Shao W, Wiegand A, Mellors J, Coffin J, Maldarelli F, Kearney M. A smalle fraction of proviruses in expanded clones express unspliced HIV RNA in vivo. In: Conference on retroviruses and opportunistic infections; Seattle, WA; 2017.

220. Kearney MF, Wiegand A, Shao W, Coffin JM, Mellors JW, Lederman M, Gandhi RT, Keele BF, Li JZ. Origin of rebound plasma HIV includes cells with identical proviruses that are transcriptionally active before stopping of antiretroviral therapy. J Virol. 2016;90(3):1369-76.

221. Lorenzi JC, Cohen YZ, Cohn LB, Kreider EF, Barton JP, Learn GH, Oliveira T, Lavine CL, Horwitz JA, Settler A, Jankovic M, Seaman MS, Chakraborty AK, Hahn BH, Caskey M, Nussenzweig MC. Paired quantitative and qualitative assessment of the replication-competent HIV-1 reservoir and comparison with integrated proviral DNA. Proc Natl Acad Sci USA. 2016;113(49):E7908-16.

222. Hosmane NN, Kwon KJ, Bruner KM, Capoferri AA, Beg S, Rosenbloom DI, Keele BF, Ho YC, Siliciano JD, Siliciano RF. Proliferation of latently infected CD4(+) T cells carrying replication-competent HIV-1: potential role in latent reservoir dynamics. J Exp Med. 2017:214(4):959-72.

223. Bui JK, Sobolewski MD, Keele BF, Spindler J, Musick A, Wiegand A, Luke BT, Shao W, Hughes SH, Coffin JM, Kearney MF, Mellors JW. Proviruses with identical sequences comprise a large fraction of the replicationcompetent HIV reservoir. PLoS Pathog. 2017;13(3):e1006283.

224. Wang Z, Gurule EE, Brennan TP, Gerold JM, Kwon KJ, Hosmane NN, Kumar MR, Beg SA, Capoferri AA, Ray SC, Ho YC, Hill AL, Siliciano JD, Siliciano RF. Expanded cellular clones carrying replicationcompetent HIV-1 persist, wax, and wane. Proc Natl Acad Sci USA. 2018;115(11):E2575-84

225. Prins JM, Jurriaans S, van Praag RM, Blaak H, van Rij R, Schellekens PT, ten Berge IJ, Yong SL, Fox CH, Roos MT, de Wolf F, Goudsmit J, Schuitemaker $\mathrm{H}$, Lange JM. Immuno-activation with anti-CD3 and recombinant human IL-2 in HIV-1-infected patients on potent antiretroviral therapy. AIDS. 1999;13(17):2405-10.

226. Kulkosky J, Nunnari G, Otero M, Calarota S, Dornadula G, Zhang H, Malin A, Sullivan J, Xu Y, DeSimone J, Babinchak T, Stern J, Cavert W, Haase
A, Pomerantz RJ. Intensification and stimulation therapy for human immunodeficiency virus type 1 reservoirs in infected persons receiving virally suppressive highly active antiretroviral therapy. J Infect Dis. 2002;186(10):1403-11.

227. Bashiri K, Rezaei N, Nasi M, Cossarizza A. The role of latency reversal agents in the cure of HIV: a review of current data. Immunol Lett. 2018;196:135-9.

228. Shan L, Deng K, Shroff NS, Durand CM, Rabi SA, Yang HC, Zhang H, Margolick JB, Blankson JN, Siliciano RF. Stimulation of HIV-1-specific cytolytic T lymphocytes facilitates elimination of latent viral reservoir after virus reactivation. Immunity. 2012;36(3):491-501.

229. Wiegand A, Spindler J, Hong FF, Shao W, Ciktor J, Cillo AR, Halvas EK, Coffin JM, Mellors JW, Kearney MF. Single-cell analysis of HIV-1 transcriptional activity reveals expression of proviruses in expanded clones during ART. Proc. Natl. Acad. Sci. USA. 2017;114(18):E3659-68.

230. Laskey SB, Pohlmeyer CW, Bruner KM, Siliciano RF. Evaluating clonal expansion of HIV-infected cells: optimization of PCR strategies to predict clonality. PLoS Pathog. 2016;12(8):e1005689.

231. Cesana D, Sgualdino J, Rudilosso L, Merella S, Naldini L, Montini E. Whole transcriptome characterization of aberrant splicing events induced by lentiviral vector integrations. J Clin Invest. 2012;122(5):1667-76.

232. Moiani A, Paleari Y, Sartori D, Mezzadra R, Miccio A, Cattoglio C, Cocchiarella F, Lidonnici MR, Ferrari G, Mavilio F. Lentiviral vector integration in the human genome induces alternative splicing and generates aberrant transcripts. J Clin Invest. 2012;122(5):1653-66.

233. Sherrill-Mix S, Ocwieja KE, Bushman FD. Gene activity in primary T cells infected with HIV89.6: intron retention and induction of genomic repeats. Retrovirology. 2015;12:79.

234. Rothe M, Modlich U, Schambach A. Biosafety challenges for use of lentiviral vectors in gene therapy. Curr Gene Ther. 2013;13(6):453-68.
Ready to submit your research? Choose BMC and benefit from:

- fast, convenient online submission

- thorough peer review by experienced researchers in your field

- rapid publication on acceptance

- support for research data, including large and complex data types

- gold Open Access which fosters wider collaboration and increased citations

- maximum visibility for your research: over 100M website views per year

At BMC, research is always in progress.

Learn more biomedcentral.com/submissions 